\title{
Risk-Dominant Scenarios from Several SRS Facilities
}

by

A. Blanchard

Westinghouse Savannah River Company

Savannah River Site

Aiken, South Carolina 29808

D. R. Marx

WSMS

E. P. Hope

WSMS

R. W. Williams

DOE Contract No. DE-AC09-96SR18500

This paper was prepared in connection with work done under the above contract number with the U.S.

Department of Energy. By acceptance of this paper, the publisher and/or recipient acknowledges the U.S. Government's right to retain a nonexclusive, royalty-free license in and to any copyright covering this paper, along with the right to reproduce and to authorize others to reproduce all or part of the copyrighted paper. 


\section{DISCLAIMER}

This report was prepared as an account of work sponsored by an agency of the United States Government. Neither the United States Government nor any agency thereof, nor any of their employees, makes any warranty, express or implied, or assumes any legal liability or responsibility for the accuracy, completeness, or usefulness of any information, apparatus, product, or process disclosed, or represents that its use would not infringe privately owned rights. Reference herein to any specific commercial product, process, or service by trade name, trademark, manufacturer, or otherwise does not necessarily constitute or imply its endorsement, recommendation, or favoring by the United States Government or any agency thereof. The views and opinions of authors expressed herein do not necessarily state or reflect those of the United States Government or any agency thereof.

This report has been reproduced directly from the best available copy.

Available to DOE and DOE contractors from the Office of Scientific and Technical Information, P.O. Box 62, Oak Ridge, TN 37831; prices available from (615) 576-8401.

Available to the public from the National Technical Information Service, U.S. Department of Commerce, 5285 Port Royal Road, Springfield, VA 22161. 


\section{DISCLAIMER}

Portions of this document may be illegible in electronic image products. Images are produced from the best available original document. 


\section{Risk-Dominant Scenarios from Several SRS Facilities (U)}

D.R. Marx, E.P. Hope, R.W. Williams

November 1998

Westinghouse Savannah River Company Aiken, SC 29808
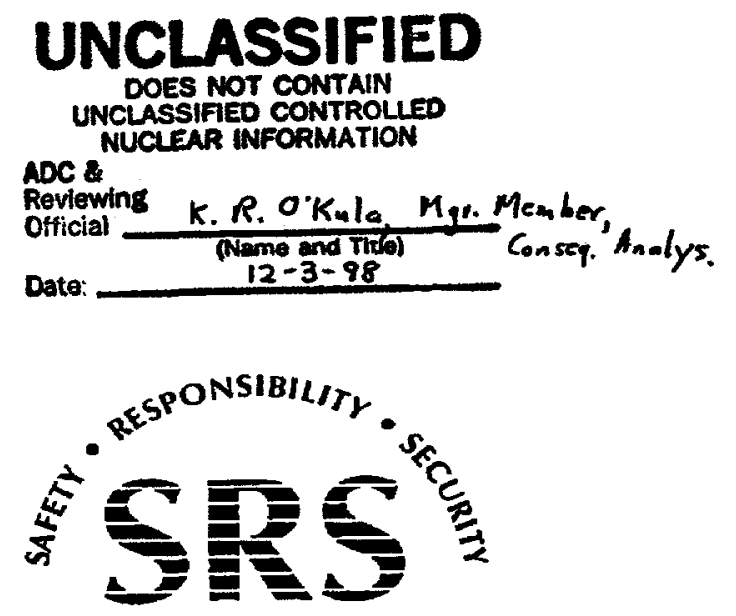

SAVANNAH RIVER SITE

PREPARED FOR THE U.S. DEPARTMENT OF ENERGY UNDER CONTRACT NO. DE-AC09-96SR18500 
Keywords:

Safety Analysis

Consequence analysis

Risk comparison

Onsite Dose

Offsite Dose

\section{Risk-Dominant Scenarios from Several SRS Facilities (U)}

D.R. Marx, E.P. Hope, R.W. Williams

November 1998

Westinghouse Savannah River Company Aiken, SC 29808

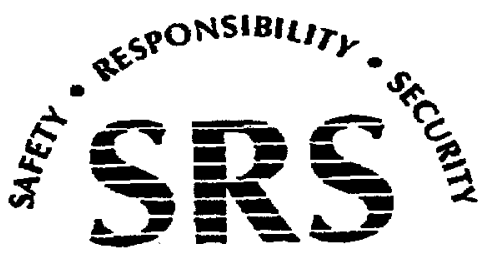

SAVANNAH RIVER SITE

PREPARED FOR THE U.S. DEPARTMENT OF ENERGY UNDER CONTRACT NO. DE-AC09-96SR18500 


\section{DISCLAIMER}

This report was prepared by Westinghouse Savannah River Company (WSRC) for the United States Department of Energy under Contract No. DE-AC09-96SR18500 and is an account of work performed under that contract. Reference herein to any specific commercial product, process, or service by trademark, name, manufacturer or otherwise does not necessarily constitute or imply endorsement, recommendation, or favoring of same by WSRC or by the United States Government or any agency thereof. The views and opinions of the authors expressed herein do not necessarily state or reflect those of the United States Government or any agency thereof. 
Project: Rocky Flats Request for Risk-Dominant Scenario Comparison

Document: WSRC-RP-98-01359

Title:

Risk-Dominant Scenarios from Several SRS Facilities (U)

WSMS Approvals:

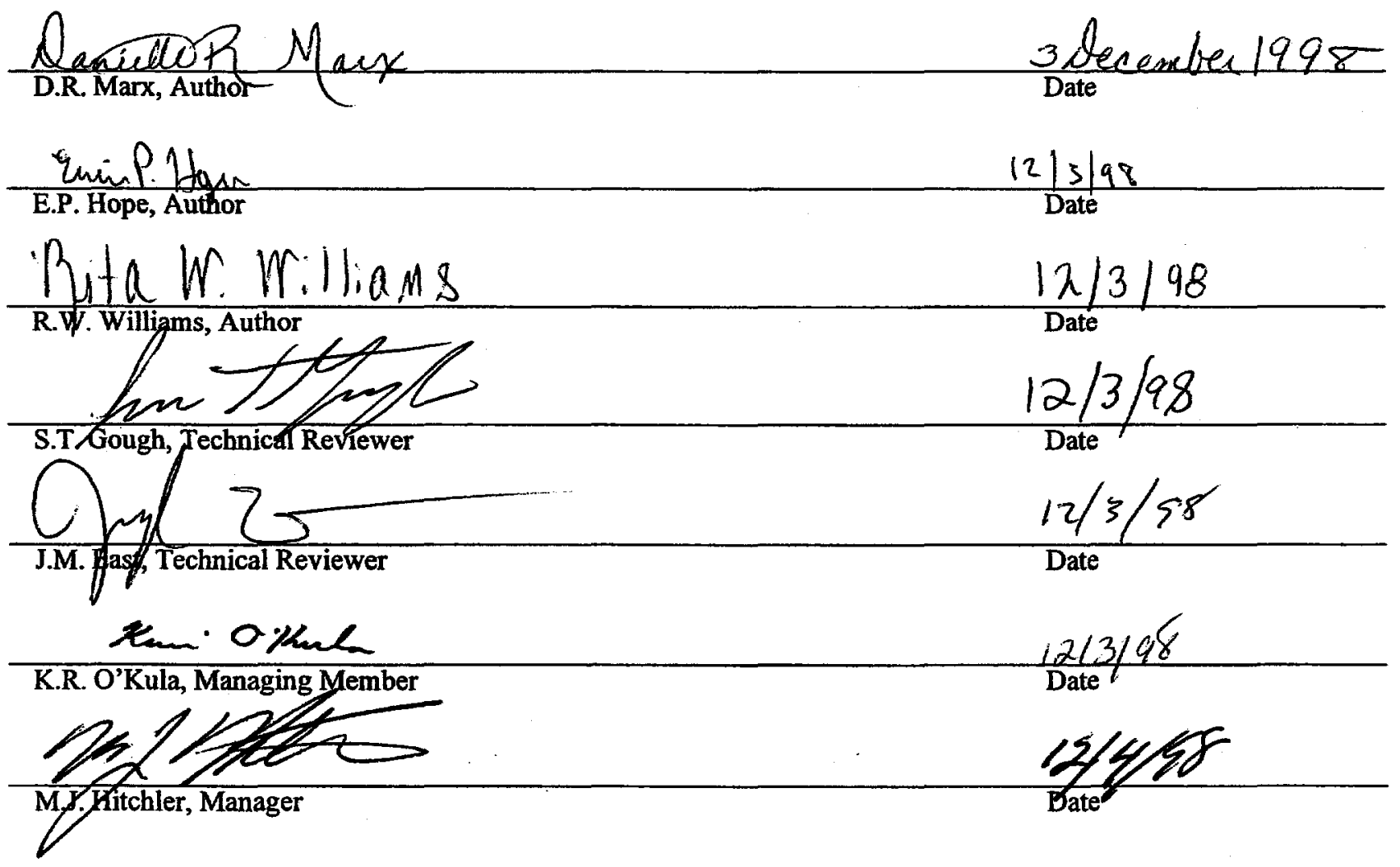


This Page Intentionally Left Blank 


\section{EXECUTIVE SUMmARY}

At the request of the DOE Rocky Flats Field Office, an examination of several postulated accidents for Savannah River Site's (SRS's) Hazard Category 2 nuclear facilities was performed. The request for this study was made following a Rocky Flats Environment Technology Site (RFETS) evaluation indicating that many postulated accidents exceed evaluation guidelines.

For this evaluation, selected events were drawn from four SRS authorization basis documents and supporting Engineering Calculations. A detailed review was conducted to extract details from the SRS accident analyses and recast information in terms of scenario spreadsheets for comparison purposes to the RFETS analyses. The accident analysis details included specific information with respect to source term evaluation, chemical form, material-at-risk, damage ratio, airborne release fractions, respirable fractions, leak path factors and event timings. Aspects of the consequence analysis review included distance to receptors, dose quantile, treatment of plume meander and surface roughness, inhalation dose factors, and plume deposition parameters.

The four SRS facilities chosen for examination were HB-Line, the proposed Actinide Packaging and Storage Facility, Building 235-F, and the Solid Waste Management Facility. For each facility, the bounding accident for each frequency bin was evaluated as discussed above. Additional events, particularly those resulting in high consequences or representing additional accident types, were evaluated if deemed necessary. Postulated accidents determined to be risk-dominant were evaluated with respect to Evaluation Guidelines and compared with RFETS facility safety analyses to determine possible differences in consequence analysis methodology between the two sets of facilities.

The analysis comparison concludes that the chief sources of difference in dose consequences may be traced to: (1) site boundary distances; (2) different meteorological basis for the onsite receptor; (3) application of lofted and non-lofted plume conditions for fire scenarios in the RFETS analyses; (4) differences in the assumed breathing rate for onsite and offsite receptors; and (5) in general, higher amounts of material-at-risk in the RFETS scenarios. 


\section{Table of Contents}

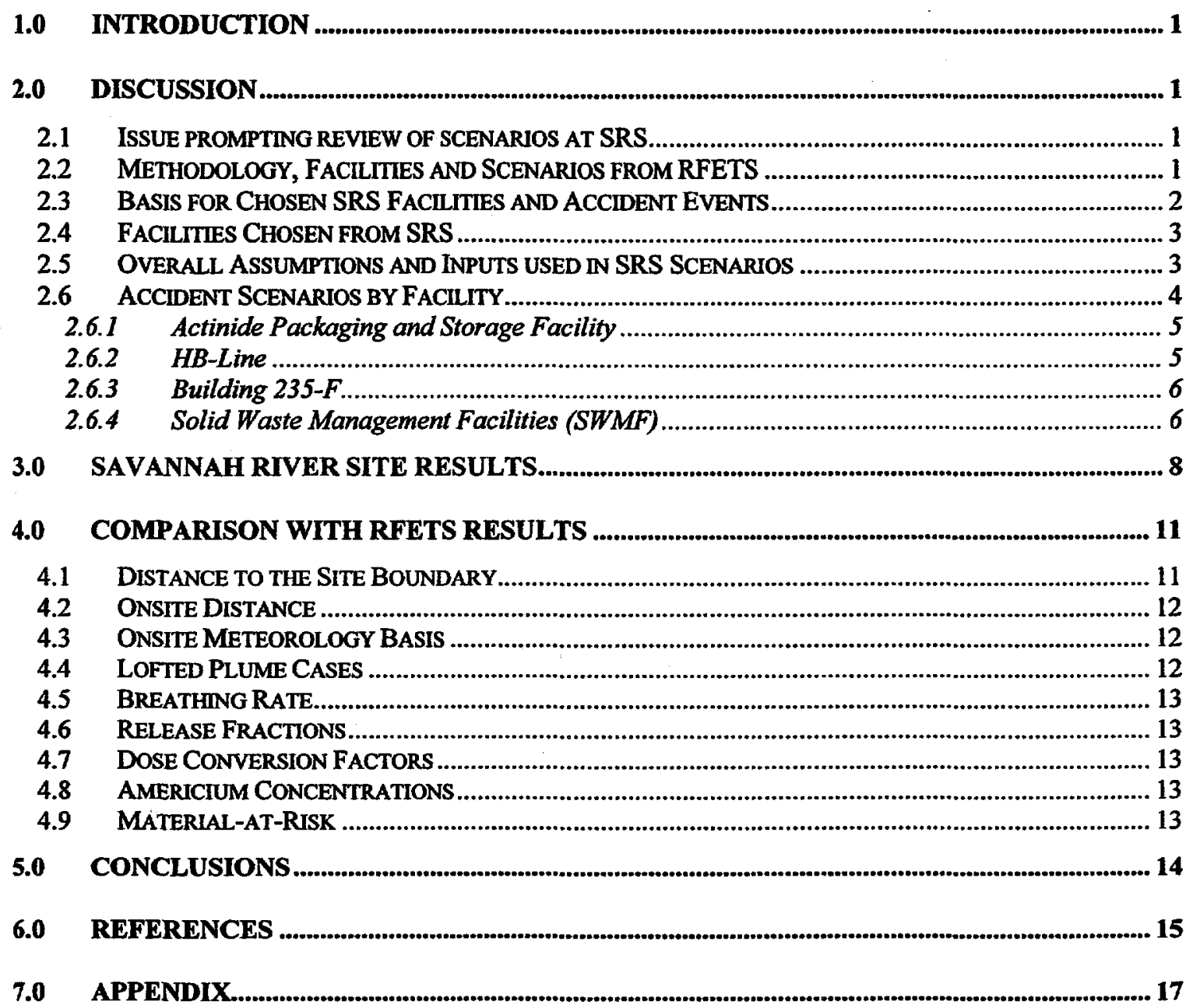




\section{This Page Intentionally Left Blank}




\subsection{INTRODUCTION}

The Department of Energy Rocky Flats Field Office (RFFO) recently summarized riskdominant scenarios for Category 2 facilities at the Rocky Flats Environmental Technology Site (RFETS). The summary is based on DOE-STD-3011-94 methodology and a spreadsheet format that follows RADIDOSE methodology (Peterson 1998). Since a number of the risk-dominant scenarios exceed RFETS guidelines, the Rocky Flats Field Office sought to compare the analyses to other similar nuclear facilities within the DOE Complex for relative risk perspectives, risk criteria, and consistency of assumptions. The DOE Savannah River Operations Office was requested to provide a set of Savannah River Site (SRS) facility-based scenarios to compare with the RFETS results.

This report and associated spreadsheets describe the SRS safety analysis provided for four selected transuranic storage and stabilization facilities. For each of the four sets of analysis, the bounding events in each frequency category are identified, key inputs and assumptions are stated, and final doses tabulated.

\subsection{Discussion}

\subsection{ISSUE PROMPTING REVIEW OF SCENARIOS AT SRS}

An examination of risk-dominant accident scenarios for Hazard Category 2 nuclear facilities at RFETS was recently conducted. This study indicated that a number of RFETS postulated accident scenarios exceeded evaluation guidelines. As a result of this study, RFFO requested SRS to review their risk-dominant scenarios for Category 2 facilities. This request was to include a comparison of relative risk perspectives, risk acceptance, and consistency of assumptions when appropriate. The TRU/TRUM waste storage facilities were of particular concern for RFFO.

\subsection{METHODOLOGY, FACILITIES AND SCENARIOS FROM RFETS}

To provide a reference for the requested comparison, SRS was provided the EXCEL spreadsheet used by RFETS to calculate consequences and risk-categories for accidents evaluated at Rocky Flats (RF). This spreadsheet includes information on the following parameters for each accident event examined:

- Material of concern and its form

- Assumed breathing rate

- Material-at-risk (MAR)

- Damage ratio (DR)

- Leakpath factor (LPF)

- Airbome release fraction (ARF)

- Inhalation Dose conversion factor (IDCF)

- Release duration (min)

- Solubility class (Y or W)

- Expansion factor
- Relative downwind air concentration $(\chi / Q)$

- Dose (rem)-occupationally exposed persons (OEP) and maximum offsite individual (MOI)

- Consequence class for OEP and MOI

- Frequency class

- Risk class and if risk-dominant

- Respirable BST

- Respirable Factor (RF) 
Within this spreadsheet, consequence (dose) is calculated as the product of the DR, MAR, LPF, RF, ARF, $\chi / \mathrm{Q}$, breathing rate, and the IDCF, divided by the expansion factor.

Following calculation of dose, the postulated radiological consequences and the frequencies for each event are assigned to a bin category based on respective values. The combination of the consequence and frequency bins determines the risk category to which the event is assigned (Table 1). Accident events assigned a risk category of I or II for either the onsite or offsite individual are determined to be risk-dominant (DOE 1994b).

Table 1. Risk-category determination based on consequence and frequency bin

\begin{tabular}{|c|c|c|c|}
\hline & \multicolumn{3}{|c|}{ Frequency of Occurrence } \\
\hline Consequence & $\begin{array}{c}\text { Extremely } \\
\text { Unlikely }\end{array}$ & Unlikely & Anticipated \\
\hline $\begin{array}{c}\text { High } \\
\text { MOI: }>\text { Srem; OEP: }>25 \text { rem }\end{array}$ & II & I & I \\
\hline Moderate & III & II & I \\
\hline Low & IV & III & III \\
\hline MOI: $<0.1$ rem; OEP: $>0.5 \mathrm{rem}$ & & & \\
\hline
\end{tabular}

In addition to the methodology used at RFETS, SRS was also provided with the completed EXCEL spreadsheets for two RF facilities, Buildings 664 and 440. The accident scenarios for each facility included in the spreadsheet are listed below:

Building 664

- SAND box puncture*

- Multi-container drop*

- Earthquake*

- Drum fire*

- Mixed drums / crates fires*

- Truck fire

- Plane crash - worst-case* and realistic*
Building 440

- Repack spill

- Multi-fire*

- Truck fire

- Aircraft crash*

- Earthquake spill*

- Drum spill

- Median crate fire

Accidents followed by an asterisk were determined to be risk-dominant following the guidelines in Table 1.

\subsection{BASIS FOR CHOSEN SRS FACILITIES AND ACCIDENT EVENTS}

The SRS facilities examined in this report were chosen based on processes occurring (or proposed to occur) at the facility and the nature of the request from Rocky Flats which requested an examination of processes similar to those at RF. Specifically, Rocky Flats requested an examination of the risk-dominant scenarios for the TRU/TRUM waste storage facility.

For each facility, the bounding events in each frequency category were examined. Additional events were included in the examination based on type of accident or consequence values as needed. Risk-dominant events are characterized by mitigated 
doses that bound others for the frequency category in question. These events may approach the Evaluation Guidelines.

\subsection{FACILITIES CHOSEN FROM SRS}

Four SRS facilities were chosen for this comparison. The four SRS facilities examined and the authorization basis documents reviewed are:

1. Actinide Packaging and Storage Facility

WSRC (1998a). Actinide Packaging and Storage Facility Preliminary Safety Analysis Report. Westinghouse Savannah River Company, Aiken, SC, WSRC-SA-35, Rev. 0.

2. HB-Line

WSRC (1998b). H-B Line Basis for Interim Operation. Westinghouse Savannah River Company, Aiken, SC, WSRC-RP-96-553, Rev. 3, Addendum 1.

3. Bldg. 235-F

WSRC (1998c). Safety Analysis-200 F-Area Savannah River Site Building 235-F Final Safety Analysis Report ( $(U)$. Westinghouse Savannah River Company, Aiken, SC, WSRC-RP-89-575, Rev.0.

\section{Solid Waste Management Facility}

WSRC (1996). Solid Waste Management Facility Safety Analysis Report. Westinghouse Savannah River Company, Aiken, SC, WSRC-SA-22, Rev. 0.

A description of the accident events chosen for each facility is given in Section 2.6.

\subsection{OVERALL ASSUMPTIONS AND INPUTS USED IN SRS SCENARIOS}

Radiological consequences for postulated accidents occurring in HB-Line, APSF, and Building 235-F were performed using the MACCS Version 1.5.11.1 consequence code [Chanin 1990; Jow 1990; Rollstin 1990; and Chanin 1993]. The MACCS input file used in each set of facility analysis is based on SRS-specific inputs and assumptions:

1) For the individual analysis, the radial ring endpoints examined are determined based on the distance from the release to the receptor(s) of concern and will, at a minimum, bound either side of the desired distance.

2) Building wake effects are not included.

3) MACCS uses the Gifford model to adjust the sigma y for plume meander due to varying averaging times. This model is only valid from the averaging time of the experimental basis for the sigma $y$, assumed to be 3 minutes, to an averaging time of 100 hours [Gifford, 1975].

4) No wet deposition is assumed. 
5) Surface roughness is assumed $100 \mathrm{~cm}$, which combines the urban attributes of the operational area with the forested features of the site. [Jow, 1990] MACCS [Jow, 1990] incorporates the change in the surface roughness using the model proposed in [AMS, 1977]. In this model, the sigma $z$ parameter is adjusted by applying the one-fifth law to the quotient of the new surface roughness divided by the Prairie Grass surface roughness $(3 \mathrm{~cm}$ ) [Haugen, 1959].

6) The site meteorological data files are composed of hourly H-Area data for the calendar years 1987 through 1991, at a measured windspeed height of 10 meters. [East, 1997].

7) The assumed breathing rate is $3.33 \times 10^{-4}$ cubic meters per second [DOE, 1989]. The same breathing rate is used for onsite and offsite receptors.

8) No shielding is assumed.

9) No evacuation and/or sheltering is assumed.

10) Dose Conversion Factors are based on Federal Guidance Reports 11 and 12. [Eckerman, 1988 and Eckerman, 1993].

11) Facility-specific distances are used to the general public receptor (MOI).

For the remaining facility, SWMF, dose calculations were performed using an estimator technique in which the MAR is determined by summing the total curies of primary TRU alpha emitters. Radiological consequences are calculated as the product of the MAR, ARF, RF, LPF, DR, and the IDCF. The IDCF used assumes that for SWMF HC-2 facilities the TRU alpha emitters are the primary contributors to total dose and the rem/Ci values for the primary alpha emitters are all similar to each other.

After determination of the potential dose for each accident event, the calculated radiological consequence and frequency for each event are assigned to a bin category as discussed in Section 2.2. As shown in Table 1 above, the combination of the consequence and frequency bins determines the risk category to which the accident event is assigned. Accident events assigned a risk category of I or II are determined to be riskdominant. For each frequency bin, the maximum radiological consequences allowed for the onsite and offsite individual are defined as the Evaluation Guidelines (Table 2).

Table 2. Onsite and offsite Evaluation Guidelines for each frequency class

\begin{tabular}{|c|c|c|}
\hline & \multicolumn{2}{|c|}{ Maximum Consequence (rem) } \\
\hline Frequency Class & Onsite & Offsite \\
\hline Anticipated & 25 & 0.5 \\
\hline Unlikely & 25 & 5 \\
\hline Extremely Unlikely & 100 & 25 \\
\hline
\end{tabular}

\subsection{ACCIDENT SCENARIOS BY FACILITY}

The following is a description of the accidents examined for each of the SRS facilities included in this report. Although many accident scenarios were examined in the documentation for each facility, only a limited number were included in this study. Inclusion of a scenario was based on several factors. These factor include using 
bounding events for each accident category and a representative event for the most severe accident categories.

\subsubsection{Actinide Packaging and Storage Facility}

The Actinide Packaging and Storage Facility (APSF) is a proposed facility for SRS. Information regarding accident scenarios for this facility was taken from the APSF Preliminary Safety Analysis Report (WSRC-SA-35, Rev. 0) Chapter 3: Hazard and Accident Analysis.

Three scenarios were examined for APSF. Each accident scenario represents the bounding consequence for the respective frequency category bin. The accidents examined were a fire starting in the Accountability Measurement room, a seismic induced full-facility fire, and an explosion in the repackaging area. These accidents were assigned to the Extremely Unlikely, Unlikely, and Anticipated frequency bins, respectively. The first release was assumed to occur over $3 \mathrm{~min}$, while the second release, aerodynamic entrainment or resuspension, was assumed to occur over 10 hours. Releases were assumed to occur from a $24.7 \mathrm{~m}$ stack.

\subsubsection{HB-Line}

Accident events for $\mathrm{HB}$-Line and their resulting consequences were taken from the Safety Analysis Addendum 1 for HB-Line BIO (WSRC-RP-96-553, Rev. 3). Six events were examined for HB-Line. These events are a full-facility fire, full-facility fire with secondary events (bounding fire event), intermediate room fire, intermediate room fire with secondary events, process spills (bounding anticipated frequency bin event) and an earthquake with secondary events (bounding non-fire event). Resuspension was examined for all events, but was not a significant contributor in all cases.

The full-facility fire involves all of the processing areas in the facility and any residual material from previous operations. A smaller fire in a single room of the facility is termed an intermediate fire. Because of uncertainty about the exact configuration of the facility inventory when a room fire may occur, conservative assumptions maximize the material at risk to the point that it contains an appreciable fraction of the entire facility inventory. The entire facility inventory is available for release in the evaluation basis earthquake. Secondary events following the seismic event contribute significantly to a release and may include resin explosion, hydrogen deflagration, or fire which may be initiated by the seismic event. In the same manner, secondary events are also postulated to occur in fire scenarios with some frequency that warrants their being assessed in the safety documentation program.

Event timing scenarios are projected in which portions of the material are released over specified time intervals based on analysis of the accident progression. While a specific accident may occur over the duration of several hours, the majority of the facility inventory may be released during a short interval during that overall time. Chemical 
forms and storage methods take a role in selection of release fractions, while in general the scope of the event is used to determine the damage ratio and the leak path factor.

\subsubsection{Building 235-F}

The facilities included in the Building 235-F analysis which contain radiological hazards include the Actinide Billet Line ( $\mathrm{NpO}_{2}$ contamination); and the Plutonium Fuel Form and Plutonium Experimental Facilities $\left(\mathrm{PuO}_{2}\right.$ contamination).

Two accident types were examined for Building 235-F: design basis earthquake with firefiltered release and facility fire. The SAR examines two types of fires for Building 235$F$, a worst case fire and a best estimate fire.

\subsubsection{Solid Waste Management Facilities (SWMF)}

For the Solid Waste Management Facility, six accident scenarios were examined. The first five events involve the TRU pads, and are representative of the different accident categories that may occur (fire \& explosion, tornado, external impact, transfer \& handling event). The culvert drum internal fire event represents a fire within a single waste drum. The sixth accident event occurs in the 643-7E Buried Waste facility. Both of these subfacilities have been categorized as Hazard Category 2. The events are assumed to be ground-level releases from $\mathrm{E}$ area. The material of interest was combined into the total $\mathrm{Ci}$ of alpha emitters present rather than individual radionuclides.

A synopsis of the accident events examined for the four SRS facilities is presented in Table 3. This summary table lists the facility and event type, the MAR and release duration, and the event frequency category. 
Table 3. SRS Scenarios

\begin{tabular}{|c|c|c|c|}
\hline Facility / Event & MAR (g) & $\begin{array}{l}\text { Release Time } \\
\text { (min) }\end{array}$ & $\begin{array}{l}\text { Frequency } \\
\text { Category }\end{array}$ \\
\hline \multicolumn{4}{|l|}{ APSF } \\
\hline AM Room Fire & $4.8 E+4$ & 3 initial; 600 resus.. & Unlikely \\
\hline $\begin{array}{l}\text { Seismic induced full } \\
\text { facility fire* }\end{array}$ & $\begin{array}{c}6.22,7.92 \mathrm{E}-5,1.58 \mathrm{E}-4 \\
\text { initial; } 0.67 \text { entrainment }\end{array}$ & $\begin{array}{l}3 \text { initial; } \\
600 \text { resuspension }\end{array}$ & Unlikely \\
\hline $\begin{array}{l}\text { Explosion in } \\
\text { Repackaging Area }\end{array}$ & $\begin{array}{c}40000 \text { oxide } \\
\text { (35200 metal-equiv) }\end{array}$ & $\begin{array}{l}3 \text { initial; } \\
600 \text { resuspension }\end{array}$ & Anticipated \\
\hline \multicolumn{4}{|l|}{ HB-Line** } \\
\hline $\begin{array}{l}\text { Full Facility Fire \& } \\
\text { Secondary Events }\end{array}$ & $\begin{array}{ll}\mathrm{Pu}-238 & 3.3 \mathrm{E}+3 \\
\mathrm{Pu}-240 & 5.9 \mathrm{E}+2\end{array}$ & $\begin{array}{l}\text { Initial: } 160 \text { total } \\
\text { Resuspension: } 600 \text { total }\end{array}$ & Extremely Unlikely \\
\hline Full Facility Fire & $\begin{array}{ll}\mathrm{Pu}-238 & 3.3 \mathrm{E}+3 \\
\mathrm{Pu}-240 & 5.9 \mathrm{E}+2\end{array}$ & $\begin{array}{l}\text { Initial: } 160 \text { total } \\
\text { Resuspension: } 600 \text { total }\end{array}$ & Extremely Unilikely \\
\hline $\begin{array}{l}\text { Intermediate Fire \& } \\
\text { Secondary Events }\end{array}$ & $\begin{array}{ll}\mathrm{Pu}-238 & 3.1 \mathrm{E}+3 \\
\mathrm{Pu}-240 & 5.4 \mathrm{E}+2\end{array}$ & $\begin{array}{c}\text { Initial: } 145 \text { total } \\
\text { Resuspension: } 600 \text { total }\end{array}$ & Unlikely \\
\hline Intermediate Fire & $\begin{array}{ll}\text { Pu-238 } & 3.1 \mathrm{E}+3 \\
\text { Pu-240 } & 5.4 \mathrm{E}+2\end{array}$ & $\begin{array}{l}\text { Initial: } 145 \text { total } \\
\text { Resuspension: } 600 \text { total }\end{array}$ & Unlikely \\
\hline Spill & $\begin{array}{cr}\mathrm{Pu}-238 & 1.2 \mathrm{E}+3 \\
\mathrm{Pu}-240 & 2.1 \mathrm{E}+2 \\
\text { init. \& resus. }\end{array}$ & $\begin{array}{c}\text { Initial: } 3 \text { total } \\
\text { Resuspension: } 600 \text { total }\end{array}$ & Anticipated \\
\hline $\begin{array}{l}\text { Earthquake with } \\
\text { Secondary Events }\end{array}$ & \begin{tabular}{cc}
\multicolumn{2}{c}{ Nitrate form } \\
Am-241 & $8.0 \mathrm{E}+2$ \\
WPu-238 & $2.7 \mathrm{E}+2$ \\
WPu-239 & $1.7 \mathrm{E}+4$ \\
WPu-240 & $7.5 \mathrm{E}+3$ \\
WPu-241 & $8.0 \mathrm{E}+2$ \\
Oxide form \\
Am-241 & $1.2 \mathrm{E}+3$ \\
Pu-239 & $6.49 \mathrm{E}+2$ \\
Pu-239 & $2.5 \mathrm{E}+4$ \\
Pu-240 & $1.1 \mathrm{E}+4$ \\
Pu-241 & $1.2 \mathrm{E}+3$ \\
\end{tabular} & $\begin{array}{c}\text { Onsite: } 45 \text { total } \\
\text { Offsite: } 600 \text { tota } \\
\text { Resuspension: } 10080 \\
\text { total }\end{array}$ & Extremely Unlikely \\
\hline Bldg. 235-F & (source terms, Ci) & & \\
\hline DBE & $\mathrm{PuO}_{2} \quad 5.0 \mathrm{E}-2$ & & Extremely Unlikely \\
\hline Fire-Best Case & $\mathrm{PuO}_{2}$ 9.00E-4 & & Unlikely \\
\hline Fire - Worst Case & $\mathrm{PuO}_{2} \quad 2.0 \mathrm{E}-1$ & & Unlikely \\
\hline SWMF & (Ci alpha emitters) & & \\
\hline TRU Pads - Fire \& Exp. & $3.2 \mathrm{E}+3$ & 60 & Unlikely \\
\hline TRU Pads - Tomado & $3.4 \mathrm{E}+3$ & 60 & Extremely Unilikely \\
\hline $\begin{array}{l}\text { TRU Pads - High-Energy } \\
\text { Vehicle Impact }\end{array}$ & $8.0 \mathrm{E}+3$ & 60 & Extremely Unlikely \\
\hline $\begin{array}{l}\text { TRU Pads - Trans. \& } \\
\text { Handling }\end{array}$ & $3.4 \mathrm{E}+3$ & 60 & Anticipated \\
\hline $\begin{array}{l}\text { TRU Pads - Internal } \\
\text { Culvert Drum Fire }\end{array}$ & $6.3 \mathrm{E}+2$ & 60 & Unlikely \\
\hline $\begin{array}{l}\text { 634-7E - Buried Waste; } \\
\text { Helicopter Crash }\end{array}$ & $2.6 \mathrm{E}+3$ & 60 & Extremely Unilikely \\
\hline
\end{tabular}

* APSF seismic induced FF fire: MAR column values are for source term; multiple values for the following forms of Pu-239, respectively: power grade; fuel grade; weapons grade; entrainment is power grade form

** HB-Line: release durations are given as intervals; times listed are for total time. 


\subsection{SAVANNAH RIVER StTe Results}

For ease of comparison between the two DOE sites, the accident analysis spreadsheet provided was completed for each of the SRS facilities examined. Due to differences in calculation methodology, not all categories contain information. For many of the accident scenarios examined, the source term rather than the MAR is provided. In cases where the source term is listed, additional parameters such as ARF, RF, LPF, DR, and respirable building source term (BST) may not be provided. The completed EXCEL spreadsheets for the four SRS facilities are located in the Appendix.

Events determined to be risk-dominant for each of the four SRS facilities were examined relative to the SRS Evaluation Guidelines (EGs). The Farmer Plots in Figures 1 and 2 graphically depict the MOI and OEP dose, respectively, in relation to the EGs for all SRS events examined. Accidents for which only frequency bins were provided were assigned a frequency value within the range of the given bin. Calculated consequences for the onsite receptor are shown for APSF, HB-Line, and Building 235-F. The SWMF SAR Hazard and Accident Analysis Chapter does not include onsite dose calculations.

Of the three events examined for APSF, the seismic induced full facility fire and the Accountability Measurement (AM) room fire approach the MOI and OEP EGs, respectively. The calculated consequence for the seismic induced fire is $1.7 \mathrm{rem}$ for the MOI. The AM room fire resulted in OEP consequences of $22 \mathrm{rem}$. The onsite receptor dose evaluation for the seismic induced full facility fire currently exceeds the guideline for the Unlikely frequency category. The facility design, material-at-risk controls, and aspects of the accident analysis are in the process of being revised.

For the Solid Waste Management Facility, two of the six events approach but do not exceed the MOI evaluation guidelines. These two events, Culvert Explosion and the TRU Pad Dropped Steel Box, resulted in calculated MOI consequences of 4.5 and 0.45 rem, respectively. The EGs for these events are $5 \mathrm{rem}$ for the explosion and $0.5 \mathrm{rem}$ for the dropped steel box. The calculated consequences are below the SRS EGs.

Of the six events examined for HB-Line, two Unlikely events approach both the OEP and MOI EGs. The calculated OEP and MOI consequences for the fire without secondary events are 2.6 and $0.36 \mathrm{rem}$, respectively. Consequences for the fire with secondary events were calculated to be $12 \mathrm{rem}$ for the OEP and $0.58 \mathrm{rem}$ for the MOI. These fall below the EGs for an Unlikely event of $25 \mathrm{rem}$ OEP and $5 \mathrm{rem}$ MOI.

For the three events examined for Building $235-\mathrm{F}$, the worst case fire initially exceeded the OEP EGs. However, physical modifications in the facility were performed and the Fire Hazard Analysis was revised. The new dose analysis reports this consequence to be well below the guideline value. 


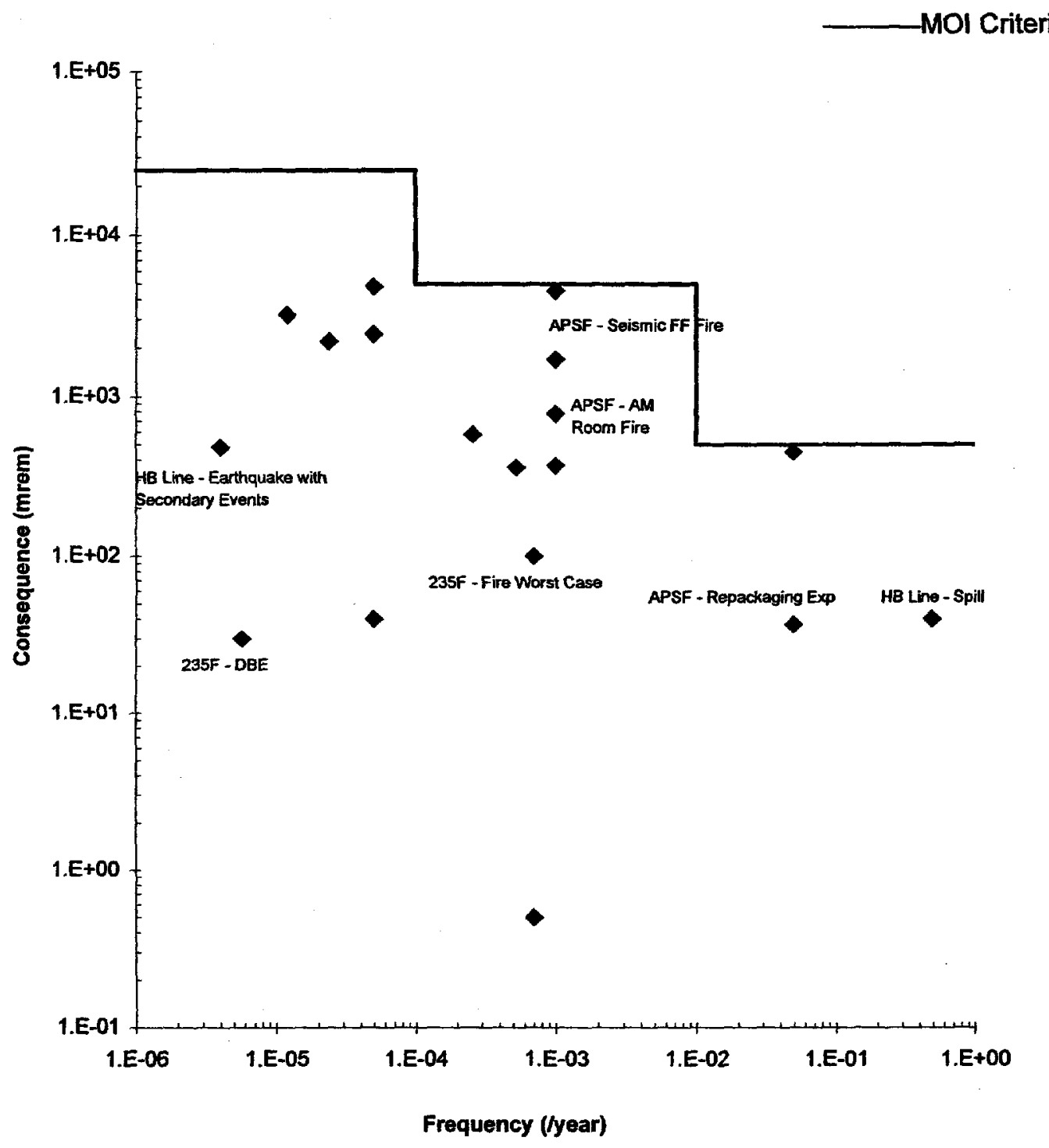

Figure 1. Farmer Plot indicating frequency of occurrence versus calculated consequences for the MOI. Events include those examined for SWMF, HB Line, Building 235-F and APSF. The solid line represents the MOI EGs for each occurrence frequency. 


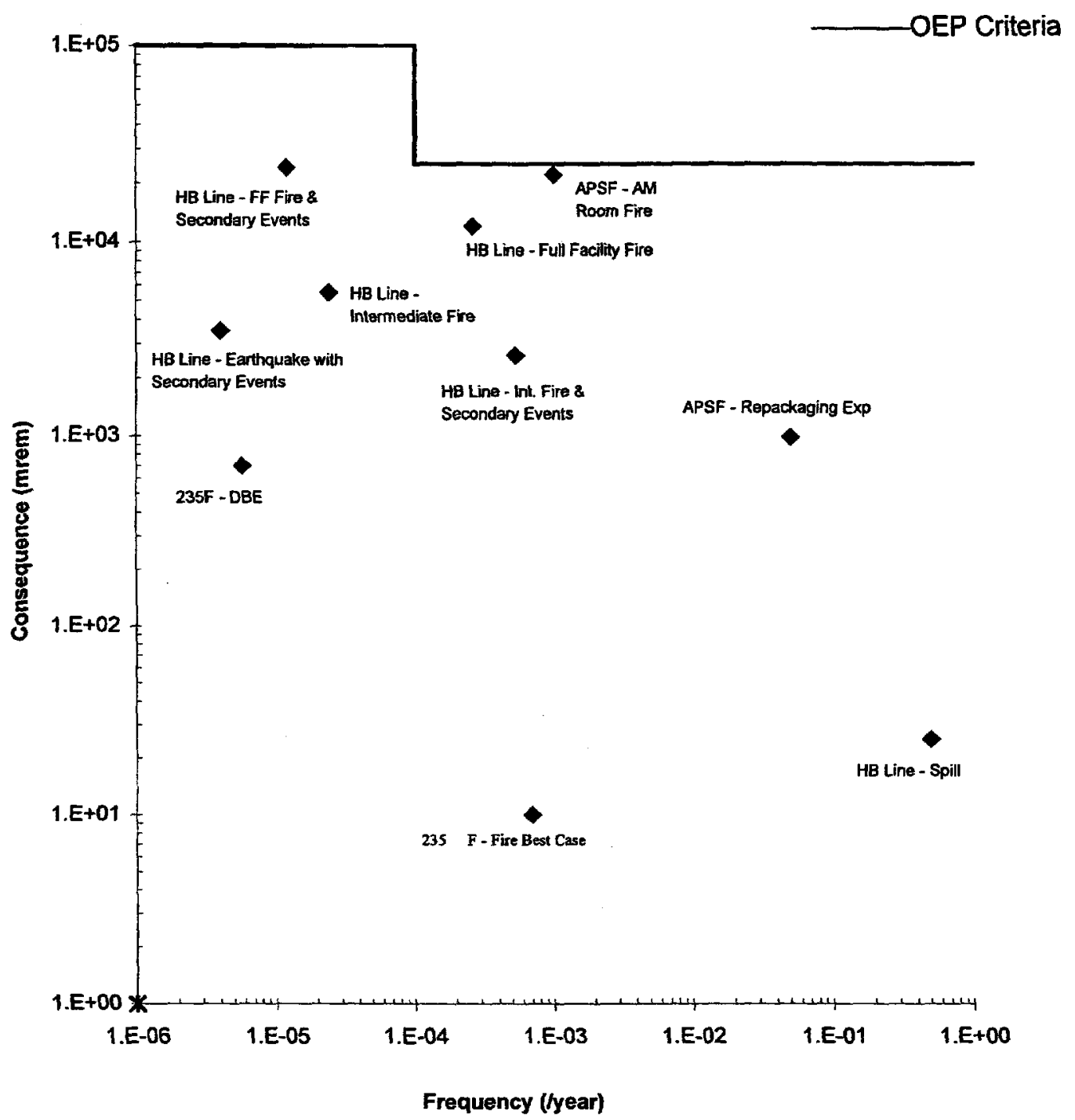

Figure 2. Farmer Plot indicating frequency of occurrence versus calculated consequences for events examined for HB Line, Building 235-F and APSF. The consequences calculated are for the OEP, or the onsite receptor. The solid line represents the OEP EGs for each occurrence frequency. 


\subsection{COMPARISON WITH RFETS RESULTS}

A comparison of the scenario spreadsheets was performed to determine the major sources of the differences in the accident and consequence analyses between the RFETS and SRS results, and the associated dose results. The key areas are with respect to distance to the site boundary, meteorological basis for the onsite receptor, lofted plume model use, breathing rates, and source terms variations.

\subsection{DisTANCE TO THE SITE BOUNDARY}

The SRS safety analysis reflects the larger distance to offsite receptors from most SRS facilities. For the SRS analyses noted in this report, all distances to the MOI receptor are considerably greater than the corresponding used in the two RFETS facility analyses. Specifically, the distance to the MOI for the SRS facility analyses are: APSF - $8.9 \mathrm{~km}$; HB-Line - $11.85 \mathrm{~km}$; 235-F $9.4 \mathrm{~km}$; and SWMF - $10.5 \mathrm{~km}$. For the two Rocky Flats facilities, the closest MOI location is $1.24 \mathrm{~km}$ for a non-lofted fire or $4.0 \mathrm{~km}$ for a lofted fire. The large differences in MOI distance for SRS as compared to RF facilities and the site-specific meteorology employed result in lower relative air concentration factors applied for postulated accident. The

Table 3. Comparison of $\chi / Q$ values for SRS and RFETS

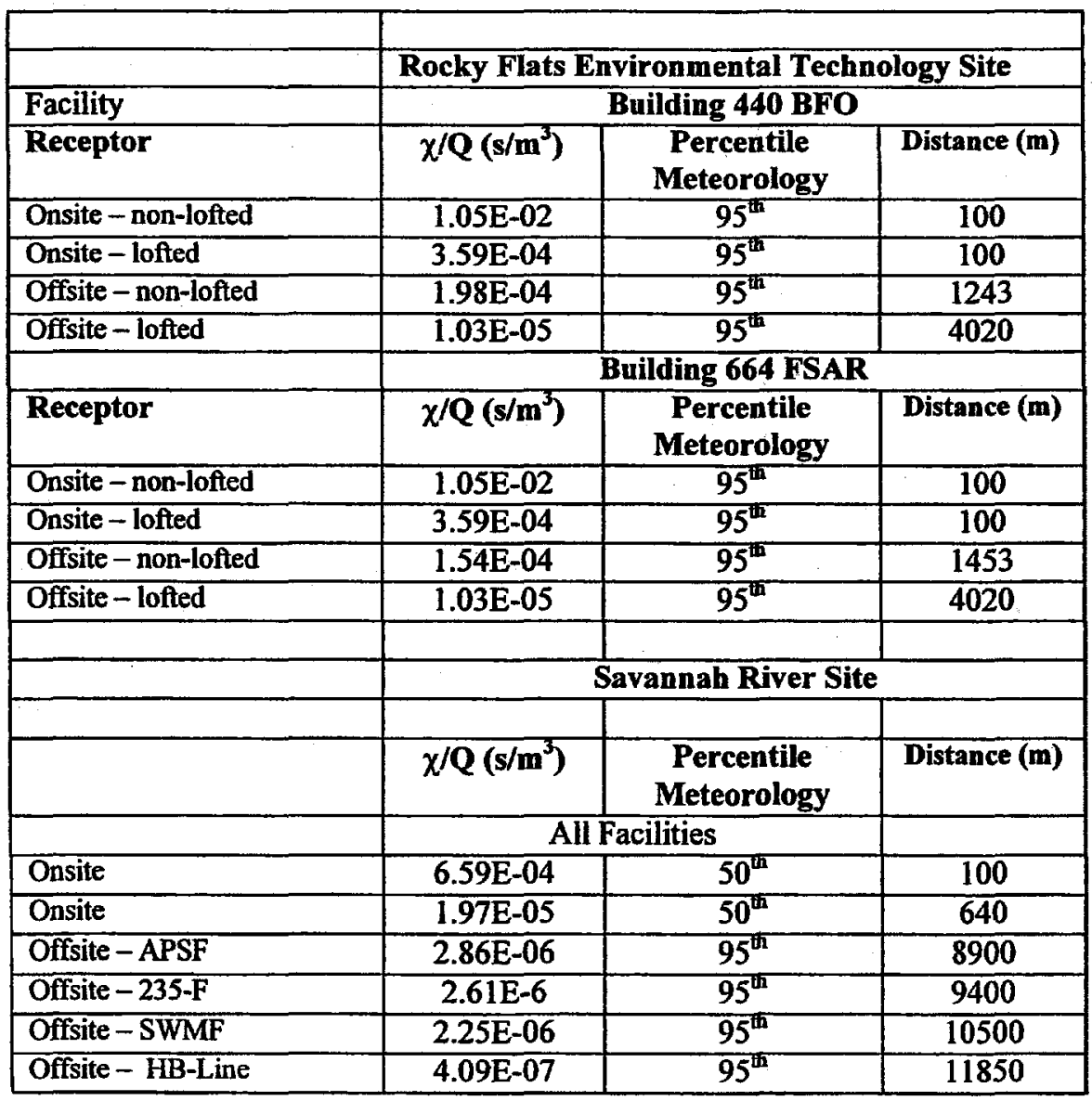


relative air concentrations, the meteorology basis, and the distance to the various receptors are listed in Table 3 for the two RFETS and the four SRS facilities.

\subsection{ONSITE DisTANCE}

The SRS and RFETS analyses appear to be consistent for the onsite receptor, using a distance of $100 \mathrm{~m}$. However, in reviewing the RFETS facility spreadsheets, it was not clear if the "lofted plume" distance remains at $100 \mathrm{~m}$ or moves to a point of plume "touchdown". Touchdown is that distance at which the plume has grown axially such that inhalation by a ground-based receptor would be possible. It was not obvious from the spreadsheet if under lofted plume conditions, ${ }^{1}$ the onsite receptor would remain within the RFETS security fence, would move to a location within the buffer zone, or be positioned outside of the boundary perimeter fence. In other words, the $95^{\text {th }}$ quantile meteorology condition and lofted plume combination is not described sufficiently to compare to the typical assumptions made in the corresponding case for lofted plume conditions in SRS analysis.

\subsection{ONSITE METEOROLOGY BASIS}

The SRS analysis for onsite receptors evaluates postulated accident conditions using median ( $50^{\text {th }}$ quantile) meteorology. This assumption has been applied to revised safety documentation at SRS since preparation of the Safety Analysis Report for the Replacement Tritium Facility in the 1993 - 1994 timeframe. At this time, WSRC Safety Engineering was directed by DOE Office of Defense Programs (DOE/DP) to use "average meteorological conditions" rather than adverse for onsite receptor evaluation (Robertson 1993). Implementation of the "average" meteorology at SRS in practice has been to use the $50^{\text {th }}$ quantile condition.

\subsection{Lofted Plume Cases}

The fire scenarios listed as part of the SRS analyses did not apply the sensible heat model in MACCS, and instead assume a ground release of radionuclides. This assumption contrasts to the lofted plume assumption available within the RADIDOSE spreadsheets. The issue of the fraction of heat released as sensible heat and therefore available to "loft" the plume versus that released as radiative heat has not been resolved nor standardized in accident analysis at SRS. Moreover, the distance to the site boundary for most SRS facilities including those compared here is such that sensible heat-impacted plumes and no sensible heat plumes result in similar air concentrations $(\chi / Q)$ to the offsite receptor. Furthermore, WSMS has some concern regarding the appropriateness of the current MACCS model for modeling areal release of sensible heat.

${ }^{1}$ Usually the onsite evaluation point is the maximally exposed onsite receptor. 


\subsection{BREATHING RATE}

The Rocky Flats analysis uses a heavy breathing rate for both the onsite and offsite receptors of $3.47 \times 10^{-4} \mathrm{~m}^{3} / \mathrm{s}$. This breathing rate corresponds to constant running. SRS analyses use an occupational breathing rate of $3.33 \times 10^{-4} \mathrm{~m}^{3} / \mathrm{s}$ for both onsite and offsite receptors.

\subsection{RELEASE Fractions}

Review of the airborne release fractions (ARF) and respirable fractions (RF) from the RADIDOSE spreadsheets does not identify any systematic difference in methodology or assumptions between RFETS and SRS radiological assessments. While in some cases specific release fractions assigned to a scenario may differ, the analyses are generally consistent.

\subsection{DOSE CONVERSION FACTORS}

Differences in the use of dose conversion factors used at the two facilities may also contribute to differences in calculated consequences. For the Rocky Flats calculations, IDCFs are for a category of material, such as weapons grade (WG) Pu, aged WG Pu, or High-Am Residues. For SRS consequence calculations, the IDCF for each isotope is used. Additionally, for the two RFETS facilities for which information was provided, all $\mathrm{Pu}$ was listed to be in the oxide form (class $\mathrm{Y}$ ). For SRS facilities, a distinction is made between the nitrate (class W) and oxide forms.

\subsection{AMERICIUM CONCENTRATIONS}

Due to the nature of the material-at-risk at RFETS, especially processes and storage of concentrations of americium in waste residues, the accident analysis for MAR containing aged weapons grade plutonium may include a disproportionate amount of americium. In contrast, SRS analysis does not generally see similar amounts of americium.

\subsection{MATERIAL-AT-RISK}

Compared to accident scenarios evaluated for SRS facilities, the maximum Rocky Flats MAR appears to be about two orders-of-magnitude higher than typically assumed for SRS analysis. 


\subsection{Conclusions}

A comparison of postulated accident scenarios has been performed for safety analyses for two Rocky Flats Environmental Technology Site facilities (Building 440 and Building 664) and four Savannah River Site facilities (APSF, HB-Line, 235-F, and SWMF). This work was in response to a request from the Rocky Flats Field Office of the Department of Energy to identify the sources of differences in the two sets of safety analyses.

This review concludes that the major points of difference include:

- Distance to the Site Boundaries, and therefore differences in the relative air concentrations for the offsite receptor evaluation

- Different meteorological basis for the onsite receptor

- Use of the lofted and non-lofted plume conditions in some of the RFETS scenarios

- Slight difference in the assumed breathing rate for onsite and offsite receptors

- In general, higher amounts of material-at-risk in the RFETS scenarios, and

- Weapons Grade components to the MAR for RFETS analysis, and often higher americium levels.

To a large extent, the analyses differences are driven by the shorter MOI distances at RFETS compared to SRS. To a lesser level, variation in the MAR and constituents to the source terms also contribute. 


\subsection{REFERENCES}

AMS (1977). "American Meteorological Society Workshop on Stability Classification Schemes and Sigma Curves -- Summary and Recommendations." Bulletin of the American Meteorological Society, Vol. 58.

D.I. Chanin (1990), J.L. Sprung, L.T. Ritchie, and H-N Jow. MELCOR Accident Consequence Code System (MACCS), Volume 1. User's Guide, Sandia National Laboratories, Albuquerque, NM. NUREG/CR-4691 (SAND86-1562).

D.I. Chanin (1993), J.A. Rollstin, J. Foster, L. Miller. MACCS Version 1.5.11.1: A Maintenance Release of the Code, Sandia National Laboratories, Albuquerque, NM NUCREG-CR-6059 (SAND92-2146).

DOE (1989). Radiation Protection for Occupational Workers, U.S. Department of Energy, Washington, DC, Order DOE 5480.11.

DOE (1994a). Recommended Values and Technical Bases for Airborne Release Fractions (ARFs), Airborne Release Rates (ARRs), and Respirable Fractions (RFs) at DOE Non-Reactor Nuclear Facilities. U.S. Department of Energy, Washington, DC, DOE-HDBK-3010-94 (December 1994).

DOE (1994b). DOE Standard: Guidance for Preparation of DOE 5480.22 (TSR) and DOE 5480.23 (SAR) Implementation Plans. U.S. Department of Energy, Washington, DC, DOE-STD-3011-94 (November 1994).

J.M. East (1997). APSF PSAR Source Term Dose Analysis (U), Westinghouse Savannah River Company, Aiken, SC, S-CLC-F-00258, Rev 1.

J.M. East (1997). Reversal of the Wind Direction for the 1987 to $1991 \mathrm{H}$ Area Meteorological Data Files (U), Savannah River Site, Aiken, SC, S-CLC-G-00162.

K.F. Eckerman, (1988) A.B. Wolbarst, A.C.B. Richardson. Limiting Values of Radionuclide Intake and Air Concentration and Dose Conversion Factors for Inhalation, Submersion, and Ingestion. Federal Guidance Report No. 11, U.S. Environmental Protection Agency, Washington, DC, DE89-011065.

K.F. Eckerman (1993) and J.C. Ryman. External Exposure to Radionuclides in Air, Water, and Soil. Federal Guidance Report 12, U.S. Environmental Protection Agency, Washington, DC, PB94-114451.WSRC (1996). Solid Waste Management Facility Safety Analysis Report. Westinghouse Savannah River Company, Aiken, SC, WSRC-SA-22, Rev. 0.

F. Gifford (1975). "Atmospheric Dispersion Models for Environmental Pollution Applications," in Lectures on Air Pollution and Environmental impact Analysis (D.A. Haugen, Ed.), American Meteorological Society, Boston, MA, pg. 45. 
D.A. Haugen, Ed. (1959). "Project Prairie Grass: A Field Program in Diffusion," Geophysical Research Papers, No. 59 Vol. III, Report AFCRC-TR-58-235, Air Force Cambridge Research Center.

H-N Jow (1990), J.L. Sprung, J.A. Rollstin, L.T. Ritchie, and D.I. Chanin. MELCOR Accident Consequence Code System (MACCS), Volume 2. Model Description. Sandia National Laboratories, Albuquerque, NM. NUREG/CR-4691 (SAND86-1562).

V. Peterson (1997), et al. Safety Analysis and Risk Assessment Handbook. Rocky Flats Environmental Technology Site, Golden, CO. RFP-5098.

S.J. Robertson (1993). Video Conference Minutes on RTF Inventory LCOs (U), Westinghouse Savannah River Company, NMP-SDG-93-0077.

J.A. Rollstin (1990), D.I. Chanin, and H-N Jow. MELCOR Accident Consequence Code System (MACCS), Volume 3. Programmer's Reference Manual, Sandia National Laboratories, Albuquerque, NM. NUREG/CR-4691 (SAND86-1562).

U. S. DOE Memorandum, S. J. Olinger to D. Jackson, Summary of Risk Dominant Scenarios, (September 1998).

WSRC (1996). Solid Waste Management Facility Safety Analysis Report. Westinghouse Savannah River Company, Aiken, SC, WSRC-SA-22, Rev. 0.

WSRC (1998a). Actinide Packaging and Storage Facility Preliminary Safety Analysis Report. Westinghouse Savannah River Company, Aiken, SC, WSRC-SA-35, Rev. 0.

WSRC (1998b). H-B Line Basis for Interim Operation. Westinghouse Savannah River Company, Aiken, SC, WSRC-RP-96-553, Rev. 3, Addendum 1.

WSRC (1998c). Safety Analysis-200 F-Area Savannah River Site Building 235-F Final Safety Analysis Report (U). Westinghouse Savannah River Company, Aiken, SC, WSRC-RP-89-575, Rev.0. 


\subsection{APPENDIX}




\begin{tabular}{|c|c|c|c|c|c|c|c|c|c|c|c|c|c|c|c|c|}
\hline & A & $\bar{B}$ & C & D & $\mathbf{E}$ & $\bar{F}$ & G & $\bar{H}$ & $T$ & $J$ & $\bar{K}$ & L & $M$ & $\bar{N}$ & 0 & $\mathbf{P}$ \\
\hline 1 & Building APSF PSAR & & & & & & & & & & & & & & & \\
\hline \multicolumn{17}{|c|}{2 Building APSF PSAR WSRC-SA-35, Rev.0 and supporting calc nole S-CLC-F-00258 } \\
\hline 3 & Review by: D.R. Marx & & & & & & & & & & & & & & & \\
\hline$\overline{4}$ & $10 / 22 / 98$ & & & & & & & & & & & & & & & \\
\hline 5 & & \multicolumn{2}{|c|}{ Calculation constants: } & & \multicolumn{3}{|c|}{ Dose Conversion Factor (rem/g) } & Class $Y$ & Class W & & & & & & & \\
\hline 6 & & \multirow[b]{2}{*}{ OlDistance (m) } & non-lofied & loffed & & & WGPU & $2.77 E+7$ & $4.28 \mathrm{E}+7$ & & & & & & & \\
\hline 7 & MO & & 8,900 & & (95\%'ile) & \multicolumn{2}{|c|}{ Aged WGPu } & $3.03 E+7$ & $4.35 \mathrm{E}+7$ & & & & & & & \\
\hline 8 & \multicolumn{2}{|c|}{ Max. Offsite Indiv. XQ $\left(\mathrm{s} / \mathrm{m}^{\wedge} \mathrm{3}\right)$} & & & (95\%'ile) & \multicolumn{2}{|c|}{ Hghi-Am Residues } & $1.92 E+8$ & $2.06 E+8$ & & & & & & & \\
\hline 9 & \multirow{2}{*}{\multicolumn{2}{|c|}{ Collocated Worker XQ $\left(\mathrm{s} / \mathrm{m}^{\wedge} 3\right)$}} & & & (50\%"ile) & & & & & & & & & & & \\
\hline 10 & & & $3.3 \mathrm{E}-4$ & & \multicolumn{2}{|c|}{ (occupational) } & & & & & & & & & & \\
\hline \multirow{2}{*}{$\frac{11}{12}$} & & & & & & & & & & & & & & & & \\
\hline & & & & Mereor- & Brealhing & Form of & Solubility & Damage & \multicolumn{2}{|c|}{ MAR or Source Term } & & Release & Expansion & & & DCF \\
\hline 13 & Scenario Description & Scenario \# & Material & ology & Rate & Material & Class & Ratio & \# items & (g) & LPF & $\begin{array}{c}\text { Duration } \\
\text { (min) }\end{array}$ & $\begin{array}{l}\text { Factor } \\
\text { (Gifford) }\end{array}$ & ARF & $\mathbf{R F}$ & $(\mathrm{rem} / \mathrm{g})$ \\
\hline 14 & & & & & & & & & & & & & & & & \\
\hline 15 & $\begin{array}{l}\text { Accountability Measurement } \\
\text { Room Fire }\end{array}$ & & $\begin{array}{l}\text { pur grade } \\
\text { Pu-239 ox. }\end{array}$ & $\begin{array}{l}50 \% \\
\text { Onsite }\end{array}$ & Occupat. & \begin{tabular}{|c|} 
max 32 containers \\
with $1.5 \mathrm{~kg}$ each
\end{tabular} & $Y$ & 1.00 & $\begin{array}{c}32 \\
\text { containers }\end{array}$ & $4.8 \mathrm{E}+4$ & $1.0 \mathrm{E}-3$ & 3 & 1.00 & $1.0 E-1$ & $7.0 \mathrm{E}-1$ & $\begin{array}{l}\text { FGR 11 } \\
\text { and } 12\end{array}$ \\
\hline 16 & & & & & & & & 1.00 & & $4.8 E+4$ & $1.0 E-3$ & 600 & 3.76 & $6.7 E-3$ & $1.0 E+0$ & $\begin{array}{l}\text { FGR } 11 \\
\text { and } 12\end{array}$ \\
\hline 17 & & & & & & & & & & & & & & & & \\
\hline 18 & $\begin{array}{l}\text { Seismic induced full facility } \\
\text { fire }\end{array}$ & $\begin{array}{c}\text { Start in MAA } \\
\text { BId }\end{array}$ & $\begin{array}{c}\text { Pu-239- } \\
\text { short term }\end{array}$ & $\begin{array}{l}50 \% \\
\text { Onsite } \\
95 \%\end{array}$ & Occupat. & $\begin{array}{c}\text { power grade; fuel } \\
\text { grade; weapons } \\
\text { grade }\end{array}$ & $Y$ & 1.00 & $\begin{array}{c}\text { Source } \\
\text { Term }\end{array}$ & $\begin{array}{c}6.22 ; 7.92 E-5 \\
1.58 E-4\end{array}$ & & 3 & 1.00 & & & $\begin{array}{l}\text { FGR } 11 \\
\text { and } 12\end{array}$ \\
\hline 19 & & & \begin{tabular}{|c|} 
Pu-239- \\
long term
\end{tabular} & $\begin{array}{l}50 \% \\
\text { Onsite }\end{array}$ & & power grade & $Y$ & 1.00 & & $6.70 \mathrm{E}-1$ & & 600 & 3.76 & & & $\begin{array}{l}\text { FGR } 11 \\
\text { and } 12\end{array}$ \\
\hline 20 & & & & & & & & & & & & & & & & \\
\hline 21 & $\begin{array}{l}\text { Explosion in Repackaging } \\
\text { Area }\end{array}$ & & $\begin{array}{c}\text { Pu-239 } \\
\text { oxide }\end{array}$ & $\begin{array}{l}50 \% \\
\text { Onsite } \\
95 \% \\
\end{array}$ & Occupat. & $\begin{array}{l}\text { power grade; } \\
\text { loose powder }\end{array}$ & $\mathbf{Y}$ & 1.00 & & $\begin{array}{l}40000 \text { oxide; } \\
\text { or } 35200 \\
\text { melat-equiv. }\end{array}$ & $1.0 \mathrm{E}-3$ & 3 & 1.00 & $5.0 \mathrm{E}-3$ & 4.0E-1 & $\begin{array}{l}\text { FGR } 11 \\
\text { and } 12\end{array}$ \\
\hline 22 & & & & & & & $Y$ & 1.00 & entrainment & & $1.0 \mathrm{E}-3$ & 600 & 3.76 & $6.72 E-03$ & $1.0 \mathrm{E}+0$ & $\begin{array}{l}\text { FGR } 11 \\
\text { and } 12\end{array}$ \\
\hline 23 & & & & & & & & & & & & & & & & \\
\hline 24 & \multicolumn{3}{|c|}{ Consequences estimated with MACCS Version 1.5.11.1 } & & & & & & & & & & & & & \\
\hline 25 & \multicolumn{16}{|c|}{ Releases, except seismic induced full fire, assumed to be from stack-level of $24.7 \mathrm{~m}$} \\
\hline 26 & \multirow{2}{*}{\multicolumn{3}{|c|}{$\begin{array}{l}\text { First release occur over } 3 \mathrm{~min} \text {, second over } 10 \text { hours } \\
\text { The MOl occurs at } 11.85 \mathrm{~km} \text { from release point }\end{array}$}} & & & & & & & & & & & & & \\
\hline 27 & & & & & & & & & & & & & & & & \\
\hline 28 & \multicolumn{2}{|c|}{ Explosion - fittered, stack level release } & & & & & & & & & & & & & & \\
\hline 29 & \multirow{2}{*}{\multicolumn{7}{|c|}{$\begin{array}{l}\text { Gifford meander factor: (release time / } 3 \text { min) })^{\wedge} 0.2 \text { if less than } 1 \mathrm{hr} \text { or } 0.25 \text { if greater than } 1 \mathrm{hr} \text { release time } \\
\text { K.F. Eckerman, (1988) A.B. Wolbarst, A.C.B. Richardson. Limiting Values of Radionuclide Intake and Air } \\
\text { Concentration and Dose Conversion Factors for Inhalation, Submersion, and Ingestion. Federal Guidance } \\
\text { Report No. 11, U.S. Environmental Protection Agency, Washington, DC, DE89-011065. }\end{array}$}} & & & & & & & & & \\
\hline 30 & & & & & & & & & & & & & & & & \\
\hline 31 & \multicolumn{7}{|c|}{$\begin{array}{l}\text { K.F. Eckerman (1993) and J.C. Ryman. Extemal Exposure to Radionuclides in Air, Water, and Soll. Federal } \\
\text { Guidance Repart 12, U.S. Environmental Protection Agency, Washinglon, DC, PB94-114451. }\end{array}$} & & & & & & & & & \\
\hline 32 & & & & & & & & & & & & & & & & \\
\hline 33 & & & & & & & & & & & & & & & & \\
\hline 34 & & & & & & & & & & & & & & & & \\
\hline 35 & & & & & & & & & & & & & & & & \\
\hline
\end{tabular}




\begin{tabular}{|c|c|c|c|c|c|c|c|c|c|}
\hline & $Q$ & $\mathbf{R}$ & $\bar{s}$ & $\mathbf{T}$ & $\bar{U}$ & V & $\bar{W}$ & $\bar{x}$ & $\bar{Y}$ \\
\hline 1 & & & & & & & & & \\
\hline 2 & & & & \multicolumn{2}{|c|}{ Risk class: } & \multicolumn{3}{|c|}{ Frequency of Occurrence } & \\
\hline 3 & & & & & & Exiremely & & & \\
\hline 4 & & & & \multicolumn{2}{|c|}{ Consequence } & Unlikely & Unlikely & Anticipated & \\
\hline 5 & & & & & High & II & $\mathrm{I}$ & $\mathrm{T}$ & \\
\hline 6 & & & & & Moderate & III & II & $I$ & \\
\hline 7 & & & & & Low & IV & III & III & \\
\hline 8 & & & & & & & & & \\
\hline 9 & & & & & & & & & \\
\hline 10 & & & & & & & & & \\
\hline 11) & & & & & & & & & \\
\hline 12 & Respirable & \multicolumn{2}{|c|}{ Collocated Worker } & \multicolumn{2}{|c|}{ Max, Oisisite Indiv. } & Frequency & \multicolumn{2}{|c|}{ Risk Class } & \\
\hline 13 & $\begin{array}{l}\text { BST } \\
(g)\end{array}$ & $\begin{array}{l}\text { Dase } \\
\text { (rem) }\end{array}$ & $\begin{array}{l}\text { Conseq. } \\
\text { Class }\end{array}$ & $\begin{array}{l}\text { Dose } \\
\text { (rem) }\end{array}$ & $\begin{array}{l}\text { Conseq. } \\
\text { Class }\end{array}$ & Class & $\mathrm{cW}$ & MOI & Scenario Description \\
\hline \multicolumn{10}{|l|}{14} \\
\hline 15 & $3.4 E+0$ & $2.0 E+1$ & Moderate & $7.8 E-1$ & Moderate & Unlikely & II & II & $\begin{array}{l}\text { Accountability Measurement } \\
\text { Room Fire }\end{array}$ \\
\hline 16 & $3.2 E-1$ & & & & & & & & \\
\hline \multicolumn{10}{|l|}{17} \\
\hline 18 & & $4.3 \mathrm{E}+1$ & High & $1.7 E+0$ & Moderate & Unlikely & I & II & $\begin{array}{l}\text { Seismic induced full facility } \\
\text { fire }\end{array}$ \\
\hline 19 & & & & & & & & & \\
\hline \multicolumn{10}{|c|}{20} \\
\hline 21 & $7.0 E-2$ & $9.1 \mathrm{E}-1$ & Moderate & $3.7 \mathrm{E}-2$ & Low & Anticipated & I & III & $\begin{array}{l}\text { Explosion in Ropackaging } \\
\text { Area }\end{array}$ \\
\hline 22 & 2.4E-01 & & & & & & & & \\
\hline 23 & & & & & & & & & \\
\hline 24 & & & & & & & & & \\
\hline 25 & & & & & & & & & \\
\hline 26 & & & & & & & & & \\
\hline 27 & & & & & & & & & \\
\hline 28 & & & & & & & & & \\
\hline 29 & & & & & & & & & \\
\hline 30 & & & & & & & & & \\
\hline 31 & & & & & & & & & \\
\hline 32 & & & & & & & & & \\
\hline 33 & & & & & & & & & \\
\hline 34 & & & & & & & & & \\
\hline 35 & & & & & & & & & \\
\hline
\end{tabular}


PSAR WSRC-SA-35 REV 0 and S-CLC-F-00258

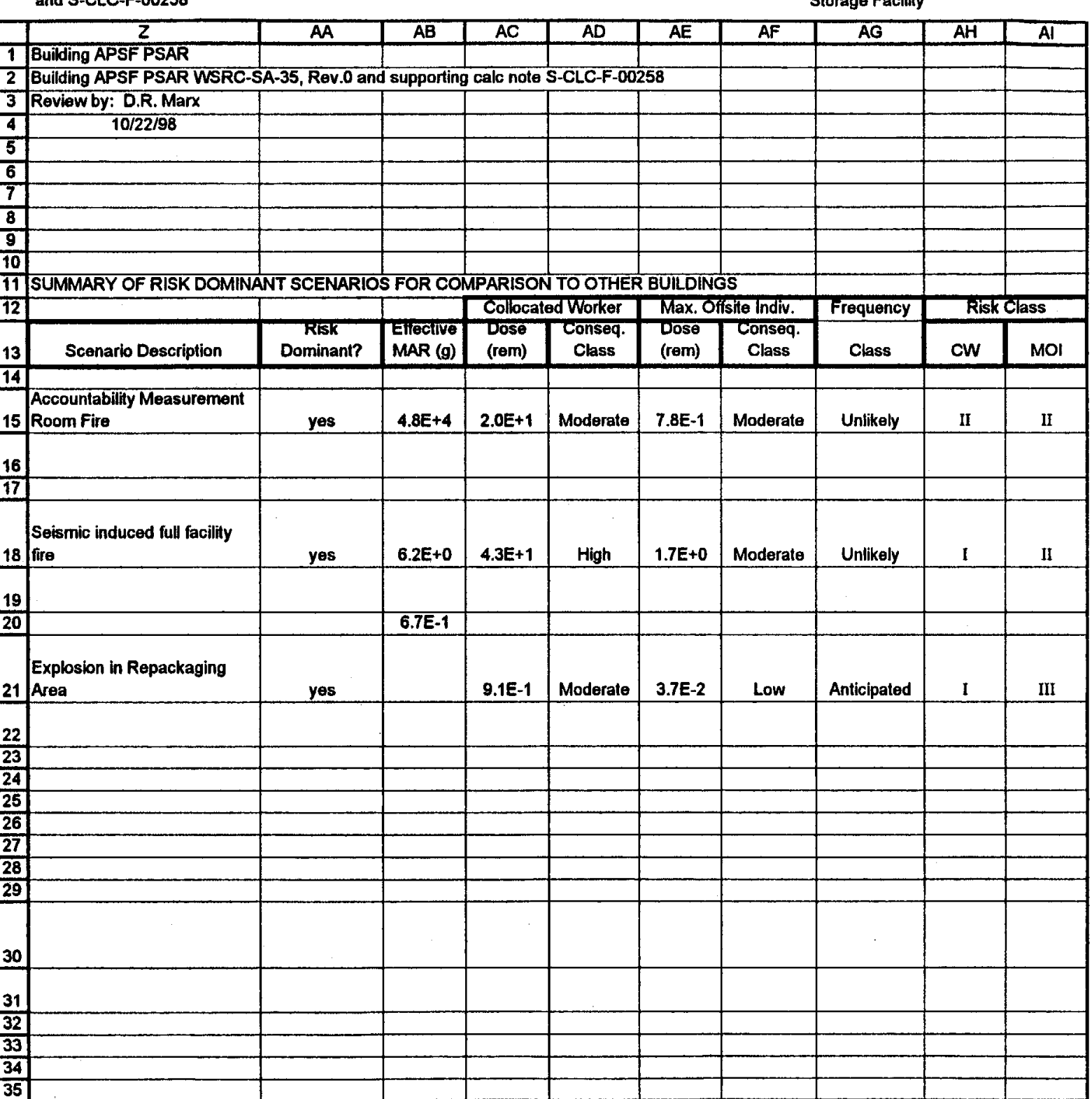


HB-Line

WSRC-RP-96-553

\begin{tabular}{|c|c|c|c|c|c|c|c|c|c|c|c|c|}
\hline & A & B & $\bar{C}$ & $\mathrm{D}$ & $\bar{E}$ & $\bar{F}$ & $\mathbf{G}$ & $\mathrm{H}$ & 1 & J & $\mathrm{K}$ & $\mathrm{L}$ \\
\hline 1 & HB-Line & & & & & & & & & & & \\
\hline 2 & \multicolumn{12}{|c|}{ HB-Line - WSRC-RP-96-553 and supporting calc notes S-CLC-H-00664 and S-CLC-H-00667 } \\
\hline 3 & Data entered by: D. Manx & & & & & & & & & & & \\
\hline 4 & $12 / 3 / 98$ & & & & & & & & & & & \\
\hline 5 & & \multicolumn{2}{|c|}{ Calculation constants: } & & & \multicolumn{3}{|c|}{ Dose Conversion Factor (rem/g) } & Class $Y$ & Class W & & \\
\hline 6 & & & & & & & & WGPU & $2.77 \mathrm{E}+7$ & $4.28 \mathrm{E}+7$ & & \\
\hline 7 & \multicolumn{2}{|r|}{ MOI Distance (m) } & 11,850 & $(95 \%$ ile) & & & \multicolumn{2}{|c|}{ Aged WGPU } & $3.03 \mathrm{E}+7$ & $4.35 E+7$ & & \\
\hline 8 & \multicolumn{2}{|c|}{ Max. Offsite Indiv. X/O (s/m³) } & $\times \times \times \times E-4$ & (95\%'ile) & & & \multicolumn{2}{|c|}{ Hghi-Am Residues } & $1.92 E+8$ & $2.06 E+8$ & & \\
\hline 9 & \multicolumn{2}{|c|}{ Collocated Worker X/Q (s/m^3) } & $\mathrm{X} \times \mathrm{XE}-2$ & (50\%'ile) & & & & & & & & \\
\hline 10 & \multicolumn{2}{|c|}{ Breathing Rate $\left(m^{\wedge} 3 / s\right)$} & $3.3 E-4$ & (occupational) & & & & & & & & \\
\hline \multirow{2}{*}{$\frac{11}{12}$} & & & & & & & & & & & & \\
\hline & & & \multicolumn{2}{|c|}{ Meteorology" } & Breathing & Form of & Solubility & Damage & MAR & BESTCF & \multicolumn{2}{|c|}{ Source Term (g) } \\
\hline 13 & Scenario Description & Material & Onsite & Offsite & Rate (m3/s) & Material & Class & Ratio & (g) & $\begin{array}{c}\text { ARF, RF, LPF for } \\
\text { onsite }\end{array}$ & Onsite & Offsite \\
\hline 14 & $\begin{array}{l}\text { SAR Farmer Event \#5 - Full } \\
\text { Facility Fire \& Secondary } \\
\text { Events }\end{array}$ & PU-238 & $5.0 \mathrm{E}-1$ & $9.5 E-1$ & $3.3 E-4$ & Oxide & $Y$ & & $3.3 E+3$ & $8.9 E-3$ & 2.1E-2 & $2.3 E+0$ \\
\hline 15 & & PU-240 & $5.0 E-1$ & 9.5E-1 & $3.3 E-4$ & Oxide & $\bar{Y}$ & & $5.9 E+2$ & $8.9 \mathrm{E}-3$ & $3.7 \mathrm{E}-3$ & 4.1E-1 \\
\hline \multicolumn{13}{|l|}{16} \\
\hline 17 & $\begin{array}{l}\text { SAR Farmer Event \#4 - Full } \\
\text { Facility Fire }\end{array}$ & PU-238 & 5.OE-1 & 9.5E-1 & 3.3E-4 & Oxide & $Y$ & & $3.3 E+3$ & $2.4 E-3$ & $3.9 E-3$ & $1.6 \mathrm{E}+0$ \\
\hline 18 & & $P \cup-240$ & $5.0 \mathrm{E}-1$ & $9.5 \mathrm{E}-1$ & $3 . \overline{3 E-4}$ & Oxide & $Y$ & & $5.9 \mathrm{E}+2$ & $2.4 E-3$ & $6.8 \mathrm{E}-4$ & $2.8 \mathrm{E}-1$ \\
\hline \multicolumn{13}{|l|}{19} \\
\hline 20 & $\begin{array}{l}\text { SAR Farmer Event } \$ 3 \text { - } \\
\text { Intermediate Fire \& } \\
\text { Secondary Events }\end{array}$ & $P U-238$ & $5.0 \mathrm{E}-1$ & $9.5 E-1$ & 3.3E-4 & Nitrate & $Y$ & & 3. $1 E+3$ & 2.7E-2 & $1.9 E-3$ & 2.7E-1 \\
\hline 21 & & $P U-240$ & $5 . \overline{0 E-1}$ & 9.5E-1 & $3.3 E-4$ & Nitrate & $\bar{Y}$ & & $5.4 E+2$ & $2.7 \mathrm{E}-2$ & $3.5 E-4$ & $4.8 E-2$ \\
\hline \multicolumn{13}{|l|}{22} \\
\hline 23 & $\begin{array}{l}\text { SAR Farmer Event \#2 - } \\
\text { Intermediate Fire }\end{array}$ & PU-238 & 5.0E-1 & $9.5 E-1$ & 3.3E-4 & Nitrate & $Y$ & & 3.1E+3 & 7.2E-3 & $1.4 \mathrm{E}-3$ & $1.9 E-1$ \\
\hline 24 & & $P U-240$ & 5.0E-1 & $9.5 \mathrm{E}-1$ & $3.3 E-4$ & Nitrate & $Y$ & & $5.4 E+2$ & 7.2E-3 & $2.3 E-4$ & $3.3 E-2$ \\
\hline \multicolumn{13}{|l|}{25} \\
\hline 26 & SAR Farmer Event \#1 - Spill & Initial PU-238 & 5.0E-1 & $9.5 E-1$ & 3.3E-4 & Oxide & $Y$ & & $1.2 \mathrm{E}+3$ & 6.7E-2 & $2.4 E-4$ & 3.5E-3 \\
\hline 27 & & Initial PU-240 & $5.0 \mathrm{E}-1$ & $9.5 E-1$ & $3.3 E-4$ & Oxide & $\bar{Y}$ & & $2.1 E+2$ & $6.7 E-2$ & $4.2 \mathrm{E}-5$ & $6.2 E-4$ \\
\hline 28 & & $\begin{array}{c}\text { resuspension } \\
\text { PU-238 }\end{array}$ & $5.0 E-1$ & 9.5E-1 & $3.3 E-4$ & Oxide & $Y$ & & $1.2 E+3$ & $6.7 E-2$ & $2.6 E-3$ & 3.9E-2 \\
\hline 29 & & $\begin{array}{c}\text { resuspension } \\
\text { PU-240 }\end{array}$ & 5.0E-1 & 9.5E-1 & 3.3E-4 & Oxide & $Y$ & & $2.1 \mathrm{E}+2$ & 6.7E-2 & 4.6E-4 & 7.0E-3 \\
\hline \multicolumn{13}{|l|}{30} \\
\hline 31 & $\begin{array}{l}\text { SAR Farmer Event } \$ 9 \text {. } \\
\text { Earthquake with Secondary } \\
\text { Events }\end{array}$ & $\begin{array}{c}\text { Nitrate release } \\
\mathrm{AM}-241\end{array}$ & 5.OE-1 & 9.5E-1 & 3.3E-4 & N/A & & & 8.0E+2 & 4.9E-3 & $2.4 E-3$ & $4.9 E-1$ \\
\hline 32 & & $P U-238$ & $5.0 E-1$ & $9.5 E-1$ & $3.3 E-4$ & Nitrate & $w$ & & $2.7 \mathrm{E}+2$ & $4.9 E-3$ & $7.8 E-4$ & $1.6 \mathrm{E}-1$ \\
\hline 33 & & $P \cup-239$ & 5.0E-1 & $9.5 E-1$ & 3.3E-4 & Nitrate & $w$ & & $1.7 \mathrm{E}+4$ & $4.9 E-3$ & $5.3 E-2$ & 1.1E+1 \\
\hline 34 & & PU-240 & $5.0 E-1$ & $9.5 E-1$ & 3.3E-4 & Nitrate & $w$ & & $7.5 E+3$ & $4.9 E-3$ & $2.2 \mathrm{E}-2$ & $4.6 E+0$ \\
\hline 35 & & PU-241 & $5.0 E-1$ & 9.5E-1 & 3.3E-4 & Nitrate & $\bar{W}$ & & $8.0 E+2$ & $4.9 E-3$ & $2.4 \mathrm{E}-3$ & $4.9 E-1$ \\
\hline 36 & & $\mathrm{~Np}-237$ & $5.0 E-1$ & $9.5 \mathrm{E}-1$ & $3.3 E-4$ & NA & & & $2.1 \mathrm{E}+4$ & $4.9 E-3$ & $7.3 E-4$ & $1.5 E-1$ \\
\hline 37 & & Oxide Release & & & & & & & & & & \\
\hline 38 & & $\mathrm{Am}-241$ & $5.0 \mathrm{E}-1$ & $9.5 \mathrm{E}-1$ & $3.3 \mathrm{E}-4$ & NA & & & $1.2 E+3$ & $4.9 E-3$ & $5.8 E-5$ & $1.2 \mathrm{E}-2$ \\
\hline 39 & & $P u-238$ & $5.0 E-1$ & $9.5 E-1$ & $3.3 E-4$ & Oxide & $\bar{Y}$ & & $6.5 E+2$ & $4.9 E-3$ & $3.7 E-7$ & $4.4 E-3$ \\
\hline 40 & & $P u-239$ & $5.0 E-1$ & $9.5 E-1$ & $3.3 E-4$ & Oxide & $Y$ & & $2.5 E+4$ & $4.9 E-3$ & $1.3 E-3$ & $2.7 E-1$ \\
\hline 41 & & Pu-240 & $5.0 E-1$ & $9.5 E-1$ & $3.3 E-4$ & Oxide & $\bar{Y}$ & & $1.1 E+4$ & $4.9 E-3$ & $5.3 E-4$ & $1.1 \mathrm{E}-1$ \\
\hline 42 & & Pu-241 & 5.0E-1 & $9.5 E-1$ & 3.3E-4 & Oxide & $\bar{Y}$ & & $1.2 \mathrm{E}+3$ & 4.9E-3 & $5.8 E .5$ & $1.2 \mathrm{E}-2$ \\
\hline 43 & & & & & & & & & & & & \\
\hline 44 & \multicolumn{2}{|c|}{ - meteorology is sector-independent } & & & & Consequen & ce class from DOE & STD-3011-9 & & & & \\
\hline 45 & * breathing rate is the DOE & cocupational brea & thing rate & & & $\begin{array}{l}\text { K.F. Eckem } \\
\text { Dose Comve } \\
\text { Protection }\end{array}$ & $\begin{array}{l}\text { nan, (1988) A.B. Wo } \\
\text { ersion Factors for In } \\
\text { Agency, Washington }\end{array}$ & $\begin{array}{l}\text { olbarst, A.C. } \\
\text { halation, Su } \\
\text { DC. DE } 89\end{array}$ & $\begin{array}{l}\text { B. Richards } \\
\text { ubmersion, } \\
011065 \text {. }\end{array}$ & $\begin{array}{l}\text { son. Limiling } \\
\text { and ingestion. }\end{array}$ & $\begin{array}{l}\text { Values of } R \\
\text { Federal } C\end{array}$ & $\begin{array}{l}\text { adionuclid } \\
\text { uidance R }\end{array}$ \\
\hline 46 & release times are modeled as & intervals, times & presented a & are the sum of $t$ & the intervals & $\begin{array}{l}\text { KF. Eckerm } \\
12 \text {. U.S. En }\end{array}$ & $\begin{array}{l}\text { nan (1993) and J.C. } \\
\text { vironmental Protect }\end{array}$ & $\begin{array}{l}\text { Ryman. Ex } \\
\text { ion Agency. }\end{array}$ & $\begin{array}{l}x \text { fernal Exp } \\
\text { Washingto }\end{array}$ & $\begin{array}{l}\text { osture to Radio } \\
\text { in, DC, P894-1 }\end{array}$ & $\begin{array}{l}\text { onuclides in } \\
114451 .\end{array}$ & Air, Water \\
\hline 47 & - dose calculated using MAC & & & & & & & & & & & \\
\hline 48 & "MOl is plume centerline EDE & at $11.85 \mathrm{~km}$ & & & & & & & & & & \\
\hline 49 & Consequence classes taken & from PHA & & & & & & & & & & \\
\hline
\end{tabular}


HB-Line

WSRC-RP-96-553

\begin{tabular}{|c|c|c|c|c|c|c|c|c|c|c|c|c|}
\hline & $\mathrm{M}$ & $\mathrm{N}$ & $\mathrm{O}$ & $P$ & $\bar{Q}$ & $R$ & $\mathrm{~S}$ & $T$ & $\mathrm{U}$ & $\bar{V}$ & $W$ & $\bar{x}$ \\
\hline 1 & & & & & & & & & & & & \\
\hline 2 & & & & & & & & & Risk class: & & & Frequency of \\
\hline 3 & & & & & & & & & & & Extremely & \\
\hline 4 & & & & & & & & & & Unlikely & Unlikely \\
\hline 5 & & & & & & & & & \multicolumn{2}{|c|}{$\frac{\text { Consequence }}{\text { High }}$} & II & 1 \\
\hline 6 & & & & & & & & & & Moderate & III & II \\
\hline 7 & & & & & & & & & & Low & IV & III \\
\hline 8 & & & & & & & & & & & & \\
\hline 9 & & & & & & & & & & & & \\
\hline 10 & & & & & & & & & & & & \\
\hline 11 & & & & & & & & & & & & \\
\hline 12 & Release & & DCF & Respirable & \multicolumn{2}{|c|}{ Dose (rem) } & & Frequency & \multicolumn{2}{|c|}{ Risk (Dose * Freq) } & \multicolumn{2}{|c|}{ Risk Class (see above) } \\
\hline 13 & $\begin{array}{c}\text { Duration } \\
\text { (min) }\end{array}$ & $\begin{array}{c}\text { Expansion } \\
\text { Factor }\end{array}$ & $($ rem/g) & $\begin{array}{l}\text { BST } \\
\text { (g) }\end{array}$ & $\begin{array}{c}\text { Site } \\
\text { Worker }\end{array}$ & $\begin{array}{c}\text { Max Offsite } \\
\text { Indiv. }\end{array}$ & $\begin{array}{c}\text { Conseq } \\
\text { Class }\end{array}$ & \&. Class & CW & MOH & $\mathrm{CW}$ & MOI \\
\hline 14 & $\begin{array}{c}\text { Initial: } 160 \\
\text { total }\end{array} \mid$ & $\begin{array}{c}\text { Gifford sigma } \\
\text { y plume } \\
\text { meander }\end{array}$ & $\begin{array}{c}\text { see FGR } \\
11 \& 12 \\
\end{array}$ & & 2. $4 E+1$ & $3.2 E+0$ & Medium & 1.2E-5 & $2.9 \mathrm{E}-4$ & $3.8 \mathrm{E}-5$ & III & III \\
\hline 15 & Res: 600 & & " & & & & & EU & & & & \\
\hline \multicolumn{13}{|c|}{\begin{tabular}{|l|l|}
16 & \\
\end{tabular}} \\
\hline 17 & $\begin{array}{c}\text { Initial: } 160 \\
\text { total }\end{array}$ & $\begin{array}{c}\text { Gifford sigma } \\
\text { y plume } \\
\text { meander }\end{array}$ & $\begin{array}{c}\text { see FGR } \\
11 \& 12\end{array}$ & & $5.5 E+0$ & $2.2 E+0$ & Medium & 2.4E-5 & $1.3 \mathrm{E}-4$ & $5.3 \mathrm{E}-5$ & III & III \\
\hline 18 & Res: 600 & & 11 & & & & & EU & & & & \\
\hline \multicolumn{13}{|l|}{19} \\
\hline 20 & $\left|\begin{array}{c}\text { Initial: } 145 \\
\text { total }\end{array}\right|$ & $\begin{array}{l}\text { Gifford sigma } \\
\text { y plume } \\
\text { meander }\end{array}$ & $\begin{array}{c}\text { see FGR } \\
11 \& 12\end{array}$ & & $1.2 E+1$ & $5.8 E-1$ & Medium & $2.6 E-4$ & $3.1 \mathrm{E}-3$ & $1.5 \mathrm{E}-4$ & II & II \\
\hline 21 & Res: 600 & & + & & & & & $U$ & & & & \\
\hline \multicolumn{13}{|c|}{22} \\
\hline 23. & $\begin{array}{c}\text { Initial: } 145 \\
\text { total }\end{array}$ & $\begin{array}{c}\text { Gifford sigma } \\
\text { y plume } \\
\text { meander }\end{array}$ & $\begin{array}{c}\text { see FGR } \\
11 \& 12\end{array}$ & & $2.6 E+0$ & 3.6E-1 & Medium & $5.3 E-4$ & $1.4 \mathrm{E}-3$ & $1.9 \mathrm{E}-4$ & I & II \\
\hline 24 & Res: 600 & & 1 & & & & & U & & & & \\
\hline \multicolumn{13}{|c|}{\begin{tabular}{l|l}
25 & \\
\end{tabular}} \\
\hline 26 & $\begin{array}{c}\text { Initial: } 3 \\
\text { total }\end{array}$ & $\begin{array}{l}\text { Gifford sigma } \\
\text { y plume } \\
\text { meander }\end{array}$ & $\begin{array}{c}\text { see FGR } \\
11 \& 12\end{array}$ & & $2.5 E-2$ & 4. OE -2 & Low & $5.0 E-1$ & 1.3E-2 & $2.0 \mathrm{E}-2$ & III & III \\
\hline 27 & & & " & & & & & $A$ & & & & \\
\hline 28 & $\begin{array}{c}\text { resp: } 600 \\
\text { total }\end{array}$ & & $\begin{array}{c}\text { see FGR } \\
11 \& 12\end{array}$ & & & & & & & & & \\
\hline 29 & & & - & & & & & & & & & \\
\hline \multicolumn{13}{|l|}{30} \\
\hline 31 & Onsite: 45 & $\begin{array}{c}\text { Giford sigma } \\
\text { y plume } \\
\text { meander }\end{array}$ & $\begin{array}{c}\text { see FGR } \\
11 \& 12\end{array}$ & & $3.5 E+0$ & $4.8 E-1$ & Medium & 4.0E-6 & $1.5 \mathrm{E}-4$ & $1.9 \mathrm{E}-6$ & III & III \\
\hline 32 & Offsite: & & 1 & & & & & EU & & & & \\
\hline 33 & $600 \mathrm{~min}$ & & $"$ & & & & & & & & & \\
\hline 34 & total & & $"$ & & & & & & & & & \\
\hline 35 & Resus.: & & $"$ & & & & & & & & & \\
\hline 36 & 10080 & & 4 & & & & & & & & & \\
\hline \multicolumn{13}{|l|}{37} \\
\hline 38 & & & $"$ & & & & & & & & & \\
\hline 39 & & & 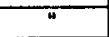 & & & & & $\because$ & & & & \\
\hline 40 & & & $"$ & & & & & & 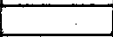 & & & \\
\hline 41 & & & $"$ & & & & & & & & & \\
\hline 42 & & & $\overline{-}$ & & & & & & & & & \\
\hline \multicolumn{13}{|l|}{43} \\
\hline \multicolumn{13}{|l|}{44} \\
\hline \multicolumn{13}{|c|}{\begin{tabular}{l|l} 
Intake and Air Concentration and \\
port No. 11, U.S. Environmental
\end{tabular}} \\
\hline 46 & and Soil. & Federal Guidan & ce Report & & & & & & & & & \\
\hline 47 & & & & & & & & & & & & \\
\hline 48 & & & & & & & & & & & & \\
\hline 49 & & & & & & & & & & & & \\
\hline
\end{tabular}




\begin{tabular}{|c|c|c|}
\hline & $\bar{Y}$ & $\bar{z}$ \\
\hline 1 & & \\
\hline 2 & Occurrence & \\
\hline 3 & & \\
\hline 4 & Anticipated & \\
\hline 5 & $I$ & \\
\hline 6 & $\mathrm{I}$ & \\
\hline 7 & III & \\
\hline 8 & & \\
\hline 9 & & \\
\hline 10 & & \\
\hline 11 & & \\
\hline 12 & & \\
\hline 13 & Scenario Description & \\
\hline 14 & $\begin{array}{l}\text { SAR Farmer Event \#5 - Full } \\
\text { Facility Fire \& Secondary } \\
\text { Events }\end{array}$ & \\
\hline 15 & & \\
\hline 16 & & \\
\hline 17 & $\begin{array}{l}\text { SAR Farmer Event \#4 - Full } \\
\text { Facility Fire }\end{array}$ & \\
\hline 10 & & \\
\hline 19 & & \\
\hline 20 & $\begin{array}{l}\text { SAR Farmer Event \#3- } \\
\text { Intermediate Fire \& } \\
\text { Secondary Events }\end{array}$ & \\
\hline 21 & & \\
\hline 22 & & \\
\hline 23 & $\begin{array}{l}\text { SAR Farmer Event \#2 - } \\
\text { Intermediate Fire }\end{array}$ & \\
\hline 24 & & \\
\hline 25 & & \\
\hline 26 & SAR Farmer Event \#1 - Spill & \\
\hline 27 & & \\
\hline 28 & & \\
\hline 29 & & \\
\hline 30 & & \\
\hline 31 & $\begin{array}{l}\text { SAR Farmer Event } \$ 9- \\
\text { Earthquake with Secondary } \\
\text { Events }\end{array}$ & \\
\hline 32 & & \\
\hline 33 & & \\
\hline 34 & & \\
\hline 35 & & \\
\hline 36 & & \\
\hline 37 & & \\
\hline 38 & & \\
\hline 39 & & \\
\hline 40 & & \\
\hline 41 & & \\
\hline 42 & & \\
\hline 43 & & \\
\hline 44 & & \\
\hline 45 & & \\
\hline 46 & & \\
\hline 47 & & \\
\hline 48 & & \\
\hline 49 & & \\
\hline
\end{tabular}




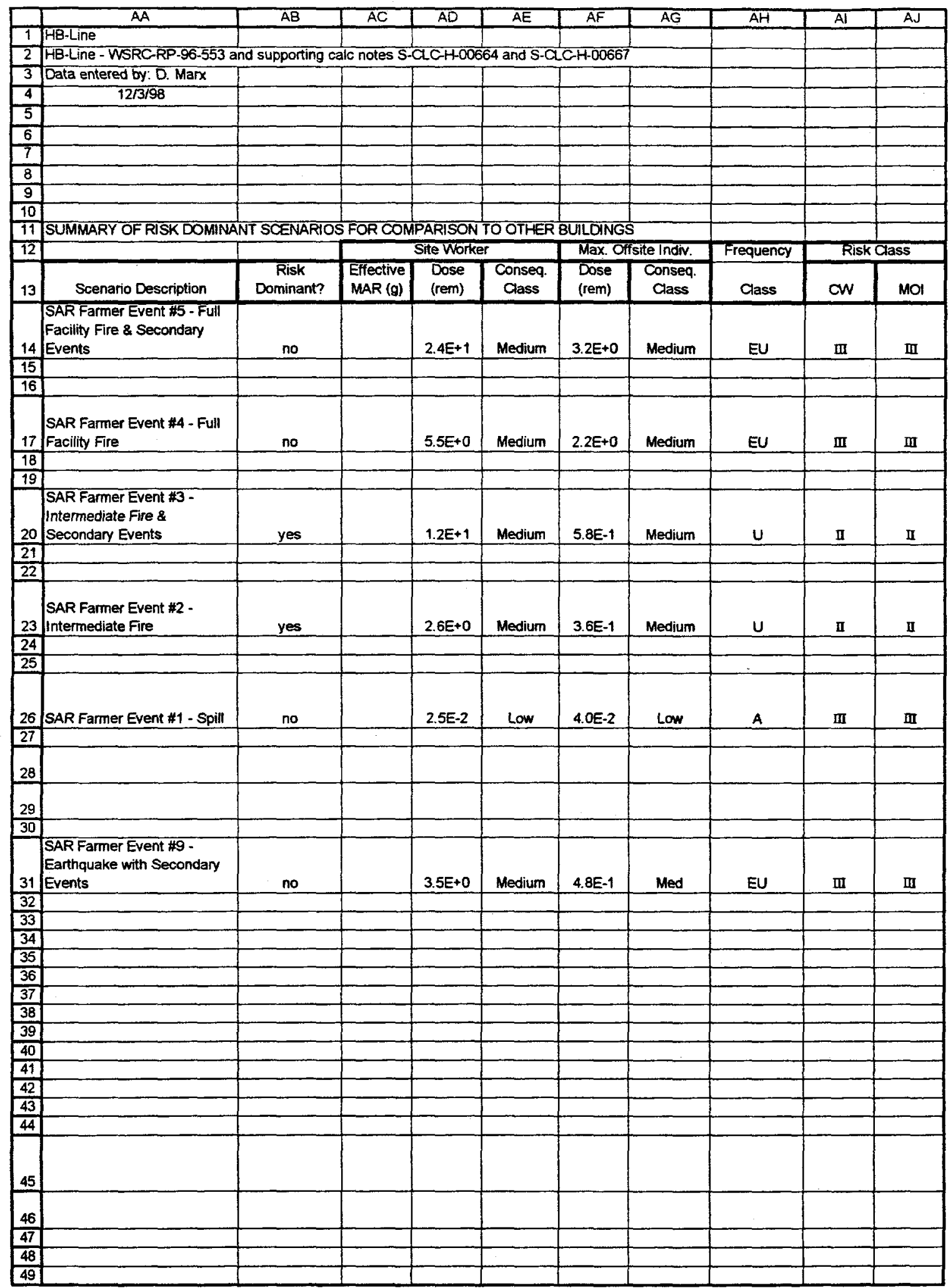




\begin{tabular}{|c|c|c|c|c|c|c|c|c|c|c|c|c|c|}
\hline & $\bar{A}$ & $\bar{B}$ & $\mathrm{C}$ & $\bar{D}$ & $\bar{E}$ & $\bar{F}$ & G & $\bar{H}$ & I & $\mathrm{J}$ & $\mathrm{K}$ & $\bar{L}$ & $\bar{M}$ \\
\hline 1 & Building 235-F SAR & & & & & & & & & & & & \\
\hline 2 & Building 235 FSAR WSRC-RP & D-89-575 & & & & & & & & & & & \\
\hline$\overline{3}$ & Review by: D.R. Marx & & & & & & & & & & & & \\
\hline 4 & $10 / 22 / 98$ & & & & & & & & & & & & \\
\hline 5 & & \multicolumn{2}{|c|}{ Calculation constants: } & & \multicolumn{3}{|c|}{ Dose Conversion Factor (rem/g) } & Class $Y$ & Class W & & & & \\
\hline 6 & & & non-lofted & lofted & & & WGPU & $2.77 \mathrm{E}+7$ & $4.28 E+7$ & & & & \\
\hline 7 & \multicolumn{2}{|c|}{ MOI Distance $(m)$} & 9,400 & & & \multicolumn{2}{|c|}{ Aged WGPu } & $3.03 E+7$ & $4.35 E+7$ & & & & \\
\hline 8 & & Max. Offsite & & & (95\%"ile) & \multicolumn{2}{|c|}{ Hghi-Am Residues } & $1.92 \mathrm{E}+8$ & $2.06 E+8$ & & & & \\
\hline 9 & Collocated Worke & $x 0(\sin 3)$ & & & (50\%'ile) & & & & & & & & \\
\hline 10 & \multicolumn{2}{|c|}{ Breathing Rate $\left(m^{\wedge} 3 / \mathrm{s}\right)$} & $3.3 E-4$ & & \multicolumn{2}{|c|}{ (occupational) } & & & & & & & \\
\hline \multirow{2}{*}{$\frac{11}{12}$} & & & & & & & & & & & & & \\
\hline & & & & Meteor- & Breathing & Form of & Solubility & Damage & \multicolumn{2}{|c|}{ Source Term } & & Releäse & \\
\hline 13 & Scenario Description & Scenario \# & Material & ology & Rate & Material & Class & Ratio & \# items & (ci) & LPF & $\begin{array}{l}\text { Duration } \\
\text { (min) }\end{array}$ & $\begin{array}{c}\text { Expansion } \\
\text { Factor }\end{array}$ \\
\hline 14 & & & & & & & & & & & & & \\
\hline 15 & Design Basis Earthquake & $\begin{array}{c}\text { Fire-Filtered } \\
\text { Release }\end{array}$ & $\begin{array}{c}\mathrm{PuO2} \\
\text { from stack }\end{array}$ & $\begin{array}{l}95 \% \text { MOI, } \\
50 \% \text { OEP }\end{array}$ & oce. & & $3-Y$ & & & $5.0 E-2$ & & & $\begin{array}{l}\text { Gindo slonis } \\
\text { ypume } \\
\text { meander }\end{array}$ \\
\hline 16 & Fire & $\begin{array}{c}\text { Best } \\
\text { Estimate }\end{array}$ & PuO2 & & occ. & & $3-Y$ & & & $9.00 E-4$ & & & \\
\hline 17 & & Worst Case & PuO2 & & occ. & & $3-Y$ & & & $2.0 E-1$ & & & $\begin{array}{c}\text { y pheme } \\
\text { meander }\end{array}$ \\
\hline \multirow{2}{*}{\multicolumn{14}{|c|}{$\frac{18}{19}$}} \\
\hline & & & & & & & & & & & & & \\
\hline \multirow{3}{*}{\multicolumn{14}{|c|}{\begin{tabular}{l|l|l|} 
& K.F. Eckerman, (1988) A.B. Wolbarst, A.C.B. Richardson. Limiting Values of Radionuclide Intake and Air \\
Concentration and Dose Conversion Factors for Inhalation, Submersion, and ingestion. Federal Guidance \\
20 \\
Report No. 11, U.S. Environmental Protection Agency. Washington, DC, DE89-011065. \\
21 & KF. Eckerman (1993) and J.C. Ryman. Extemal Exposure to Radionuclides in Air. Water, and Soil. Federal \\
22 & Guidance Report 12, U.S. Environmental Protection Agency, Washington, DC, PBg4-114451. \\
2
\end{tabular}}} \\
\hline & & & & & & & & & & & & & \\
\hline & & & & & & & & & & & & & \\
\hline \multirow{2}{*}{\multicolumn{14}{|c|}{$\frac{23}{24}$}} \\
\hline & & & & & & & & & & & & & \\
\hline \multicolumn{14}{|l|}{25} \\
\hline \multirow{2}{*}{\multicolumn{14}{|c|}{$\frac{26}{27}$}} \\
\hline & & & & & & & & & & & & & \\
\hline \multicolumn{14}{|l|}{28} \\
\hline 29 & & & & & & & & & & & & & \\
\hline 30 & & & & & & & & & & & & & \\
\hline
\end{tabular}


Building 235-F

\begin{tabular}{|c|c|c|c|c|c|c|c|c|c|c|c|c|}
\hline & $N$ & 응 & $\bar{P}$ & Q & $R$ & $\bar{s}$ & $\bar{T}$ & $\bar{U}$ & $\bar{v}$ & $\bar{W}$ & $\bar{x}$ & $\bar{Y}$ \\
\hline 1 & & & & & & & & & & & & \\
\hline 2 & & & & & & \multicolumn{3}{|c|}{ Risk class: } & \multicolumn{3}{|c|}{ Frequency of Occurrence } & \\
\hline 3 & & & & & & & & & Extremely & & & \\
\hline 4 & & & & & & & \multicolumn{2}{|c|}{ Consequence } & Unlikely & Unlikely & \multicolumn{2}{|l|}{ Anticipated } \\
\hline 5 & & & & & & & & High & II & $\bar{I}$ & $\mathrm{I}$ & \\
\hline 6 & & & & & & & & Moderate & III & II & $\mathrm{I}$ & \\
\hline 7 & & & & & & & & Low & IV & $\overline{\text { III }}$ & III & \\
\hline 8 & & & & & & & & & & & & \\
\hline $\begin{array}{ll}9 \\
\end{array}$ & & & & & & & & & & & & \\
\hline 10 & & & & & & & & & & & & \\
\hline 11 & & & & & & & & & & & & \\
\hline 12 & & & DCF & Respirable & \multicolumn{2}{|c|}{ Collocated Worker } & \multicolumn{2}{|c|}{ Max. Offsite Indiv. } & Frequency & \multicolumn{2}{|c|}{ Risk Class } & \\
\hline 13 & ARF & RF & $($ rem/g) & $\begin{array}{l}\text { BST } \\
\text { (g) }\end{array}$ & $\begin{array}{l}\text { Dose } \\
\text { (rem) }\end{array}$ & $\begin{array}{c}\text { Conseq. } \\
\text { Class }\end{array}$ & $\begin{array}{l}\text { Dose } \\
\text { (rem) }\end{array}$ & $\begin{array}{l}\text { Conseq. } \\
\text { Class }\end{array}$ & Class & CW & MOI & Scenario Description \\
\hline 14 & & & & & & & & & & & & \\
\hline 15 & 1.0E-3 & $1.0 E+0$ & $\begin{array}{l}\text { see FGR } \\
11 \& 12 \\
\end{array}$ & & $7.0 \mathrm{E}-1$ & Moderate & $3.0 \mathrm{E}-2$ & Low & 6E-06 EU & III & IV & Design Basis Earthquake \\
\hline 16 & & $1.0 E+0$ & $\begin{array}{l}\text { see FGR } \\
11 \& 12\end{array}$ & & $1.0 E-2$ & Low & $5.0 \mathrm{E}-4$ & Low & $7 E-04 U$ & III & III & Fire \\
\hline 17 & & $1.0 E+0$ & $"$ & & $7.0 E+1$ & High & $1.0 E-1$ & Low & Unlikely & 1 & III & \\
\hline 18 & & & & & & & & & & & & \\
\hline 19 & & & & & & & & & & & & \\
\hline 20 & & & & & & & & & & & & \\
\hline 21 & & & & & & & & & & & & \\
\hline 22 & & & & & & & & & & & & \\
\hline 23 & & & & & & & & & & & & \\
\hline 24 & & & & & & & & & & & & \\
\hline 25 & & & & & & & & & & & & \\
\hline 26 & & & & & & & & & & & & \\
\hline 27 & & & & & & & & & & & & \\
\hline 28 & & & & & & & & & & & & \\
\hline 29 & & & & & & & & & & & & \\
\hline 30 & & & & & & & & & & & & \\
\hline
\end{tabular}




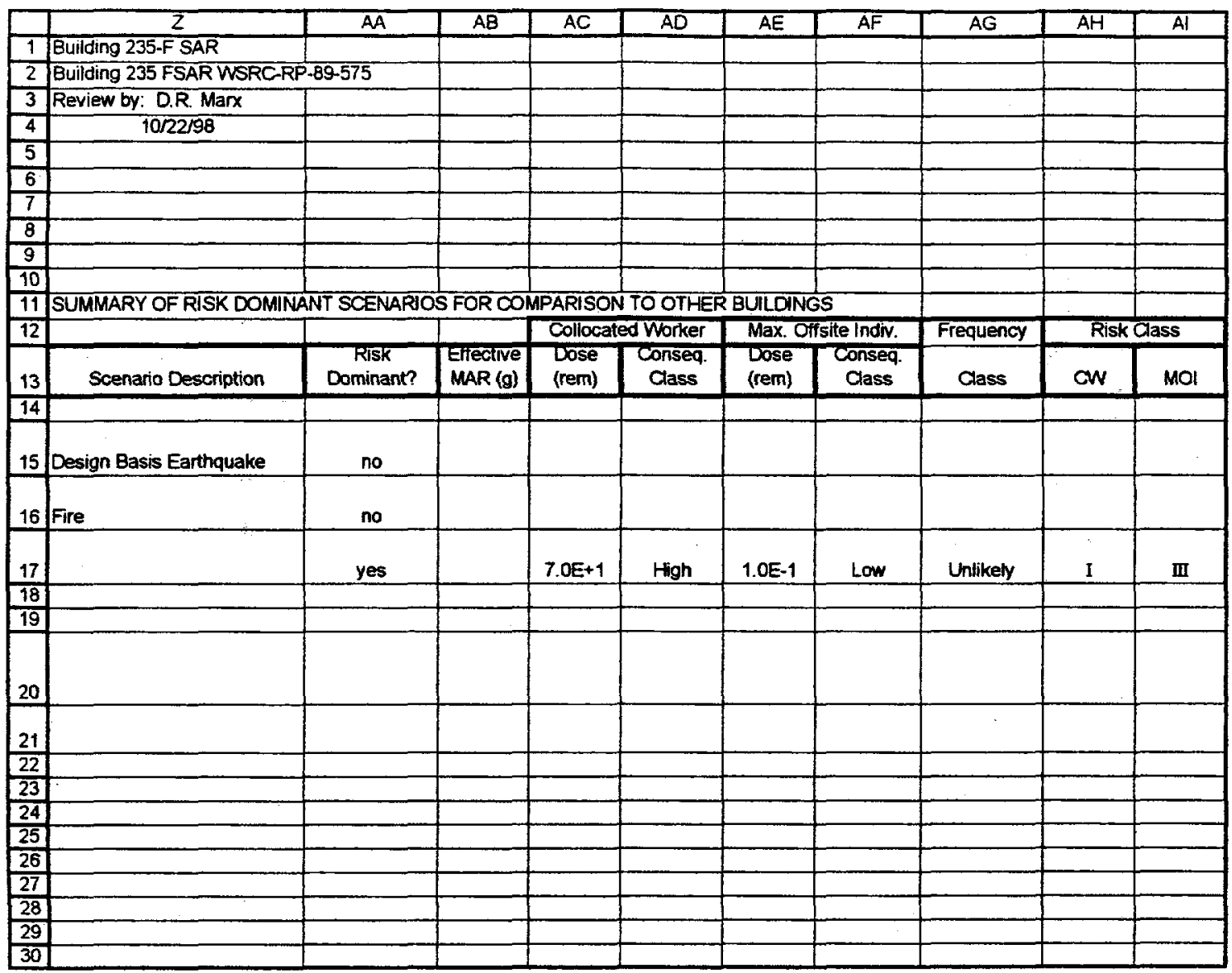




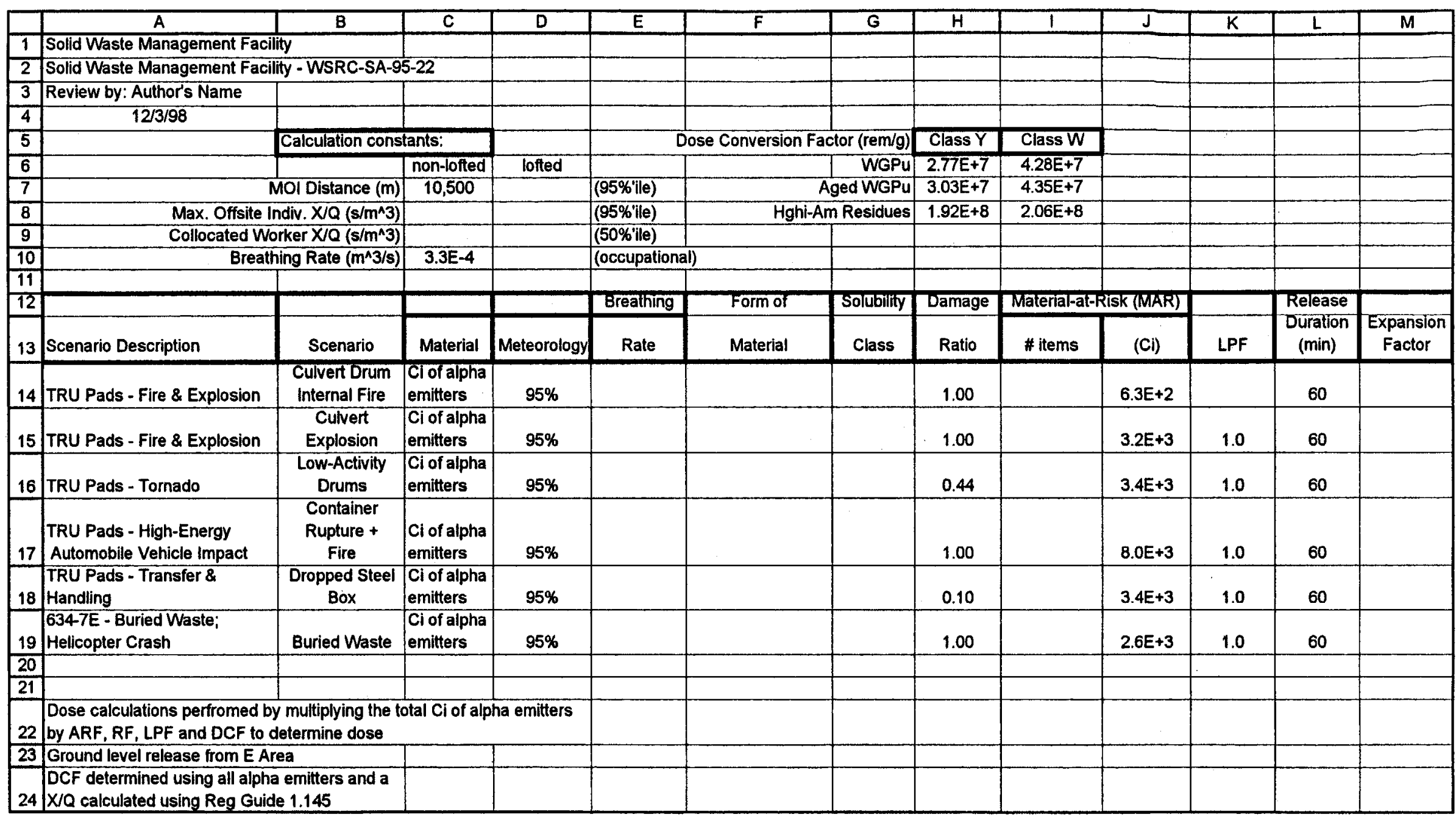




\begin{tabular}{|c|c|c|c|c|c|c|c|c|c|c|c|c|}
\hline & $\mathrm{N}$ & 0 & $\mathrm{P}$ & $\mathbf{Q}$ & $R$ & 5 & $T$ & $\mathrm{U}$ & $\mathrm{V}$ & $\bar{W}$ & $\bar{x}$ & $\mathbf{Y}$ \\
\hline 1 & & & & & & & & & & & & \\
\hline 2 & & & & & & & \multicolumn{2}{|l|}{ Risk class: } & \multicolumn{3}{|c|}{ Frequency of Occurrence } & 3 \\
\hline 3 & & & & & & & & & Extremely & & & \\
\hline 4 & & & & & & & \multicolumn{2}{|c|}{ Consequence } & Unlikely & Unlikely & \multicolumn{2}{|l|}{ Anticipated } \\
\hline 5 & & & & & & & & High & II & I & I & \\
\hline 6 & & & & & & & & Moderate & III & II & I & \\
\hline 7 & & & & & & & & Low & IV & III & III & \\
\hline 8 & & & & & & & & & & & & \\
\hline 9 & & & & & & & & & & & & \\
\hline 10 & & & & & & & & & & & & \\
\hline 11 & & & & & & & & & & & & \\
\hline 12 & & & DCF & Respirable & \multicolumn{2}{|c|}{ Collocated Worker } & \multicolumn{2}{|c|}{ Max. Orisitelnaiv. } & Frequency & \multicolumn{2}{|c|}{ Risk Class } & \\
\hline 13 & ARF*RF & & (rem/Cl) & $\begin{array}{c}\text { BST } \\
(g)\end{array}$ & $\begin{array}{l}\text { Dose } \\
\text { (rem) }\end{array}$ & $\begin{array}{c}\text { Conseq. } \\
\text { Class }\end{array}$ & $\begin{array}{l}\text { Dose } \\
\text { (rem) }\end{array}$ & $\begin{array}{c}\text { Conseq. } \\
\text { Class }\end{array}$ & Class & CW & MOI & Scenario Description \\
\hline 14 & 5.0E-4 & & 1.18 & & & & $3.7 E-1$ & Moderate & Unlikely & & II & TRU Pads - Fire \& Explosion \\
\hline 15 & $1.0 \mathrm{E}-3$ & & 1.18 & & & & 4.52 & Moderate & Unlikely & & II & TRU Pads - Fire \& Explosion \\
\hline 16 & $2.0 \mathrm{E}-4$ & & 1.18 & & & & 0.04 & Low & $\begin{array}{l}\text { Extremely } \\
\text { Unlikely }\end{array}$ & & IV & TRU Pads - Tornado \\
\hline 17 & $5.0 \mathrm{E}-4$ & & 1.18 & & & & 4.81 & Moderate & $\begin{array}{l}\text { Extremely } \\
\text { Unlikely }\end{array}$ & & III & $\begin{array}{l}\text { TRU Pads - High-Energy } \\
\text { Automabile Vehicle Impact }\end{array}$ \\
\hline 18 & $1.1 \mathrm{E}-3$ & & 1.18 & & & & 0.45 & Moderate & Anticipated & & $I$ & $\begin{array}{l}\text { TRU Pads - Transfer \& } \\
\text { Handling }\end{array}$ \\
\hline 19 & $1.0 \mathrm{E}-3$ & & 1.18 & & & & 2.44 & Moderate & $\begin{array}{l}\text { Extremely } \\
\text { Unlikely }\end{array}$ & & III & $\begin{array}{l}\text { 6347E - Buried Waste; } \\
\text { Helicopter Crash }\end{array}$ \\
\hline 20 & & & & & & & & & & & & \\
\hline 21 & & & & & & & & & & & & \\
\hline 22 & & & & & & & & & & & & \\
\hline 23 & & & & & & & & & & & & \\
\hline 24 & & & & & & & & & & & & \\
\hline
\end{tabular}




\begin{tabular}{|c|c|c|c|c|c|c|c|c|c|c|}
\hline & $\mathbf{Z}$ & AA & $\overline{A B}$ & $\overline{\mathrm{AC}}$ & $\overline{A D}$ & $\overline{\mathrm{AE}}$ & AF & $\overline{A G}$ & $\mathrm{AH}$ & Al \\
\hline 1 & \multicolumn{2}{|l|}{ Solid Waste Management Facility } & & & & & & & & \\
\hline 2 & \multicolumn{3}{|c|}{ Solid Waste Management Facility - WSRC-SA-95-22 } & & & & & & & \\
\hline 3 & Review by: Author's Name & & & & & & & & & \\
\hline 4 & $12 / 3 / 98$ & & & & & & & & & \\
\hline \multicolumn{11}{|l|}{5} \\
\hline \multicolumn{11}{|l|}{6} \\
\hline \multicolumn{11}{|l|}{7} \\
\hline \multicolumn{11}{|l|}{8} \\
\hline \multicolumn{11}{|l|}{9} \\
\hline \multicolumn{11}{|l|}{10} \\
\hline 11 & \multicolumn{7}{|c|}{ SUMMARY OF RISK DOMINANT SCENARIOS FOR COMPARISON TO OTHER BUILDINGS } & & & \\
\hline 12 & & & & Colloca & Worker & Max.0 & Gite Indiv. & Frequency & & ass \\
\hline 13 & Scenario Description & Risk Dominant? & $\begin{array}{l}\text { Efiective } \\
\text { MAR (g) }\end{array}$ & $\begin{array}{l}\text { Dose } \\
\text { (rem) }\end{array}$ & $\begin{array}{l}\text { Conseq. } \\
\text { Class }\end{array}$ & $\begin{array}{l}\text { Dose } \\
\text { (rem) }\end{array}$ & $\begin{array}{l}\text { Conseq. } \\
\text { Class }\end{array}$ & Class & CW & MOI \\
\hline 14 & TRU Pads - Fire \& Explosion & yes & $6.3 E+2$ & & & $3.7 \mathrm{E}-1$ & Moderate & Unlikely & & II \\
\hline 15 & TRU Pads - Fire \& Explosion & yes & $3.2 E+3$ & & & 4.5E+0 & Moderate & Unlikely & & II \\
\hline 16 & TRU Pads - Tornado & no & & & & & & & & \\
\hline 17 & $\begin{array}{l}\text { TRU Pads - High-Energy } \\
\text { Automobile Vehicle Impact }\end{array}$ & no & & & & & & & & \\
\hline 18 & $\begin{array}{l}\text { TRU Pads - Transfer \& } \\
\text { Handling }\end{array}$ & yes & $3.4 \mathrm{E}+2$ & & & $4.5 \mathrm{E}-1$ & Moderate & Anticipated & & I \\
\hline 19) & $\begin{array}{l}\text { 634-7E - Buried Waste; } \\
\text { Helicopter Crash }\end{array}$ & no & & & & & & & & \\
\hline 20 & & & & & & & & & & \\
\hline 21 & & & & & & & & & & \\
\hline 22 & & & & & & & & & & \\
\hline 23 & & & & & & & & & & \\
\hline 24 & & & & & & & & & & \\
\hline
\end{tabular}




\section{Distribution}

\section{DOE/Rocky Flats Field Office:}
S. J. Olinger
D. Lowe

DOE/Savannah River Operations Office:
L. E. Tripp
D. Jackson
D. Dearolph

Rocky Flats Environmental Technology Site:

T. Foppe

V. Peterson

Westinghouse Savannah River Company:

W. J. Johnson

A. E. Blanchard

Westinghouse Safety Management Solutions:

F. Beranek

M. J. Hitchler

L. A. Wooten

K. R. O'Kula

D. R. Marx

E. P. Hope

R. W. Williams

W.J. Copeland

D. K. Allison

L. M. Polizzi

R. Lopez 